In cooperation with La Luna Biological Consulting

\title{
Field Surveys of Rare Plants on Santa Cruz Island, California, 2003-2006: Historical Records and Current Distributions
}

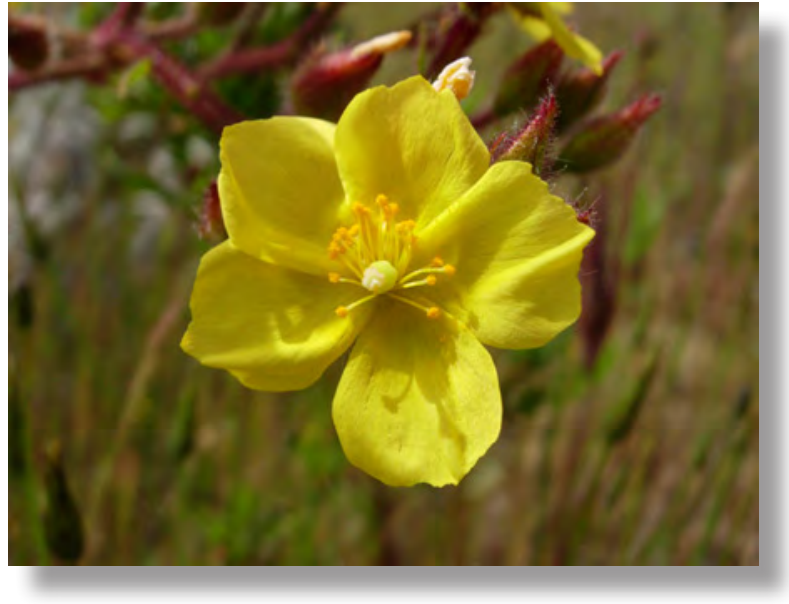

Island rush-rose

(Helianthemum greenei)

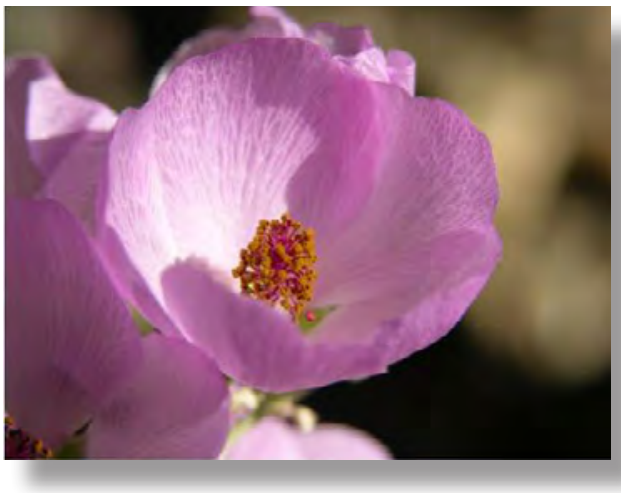

Santa Cruz Island bush mallow (Malacothamnus fasciculatus var. nesioticus)

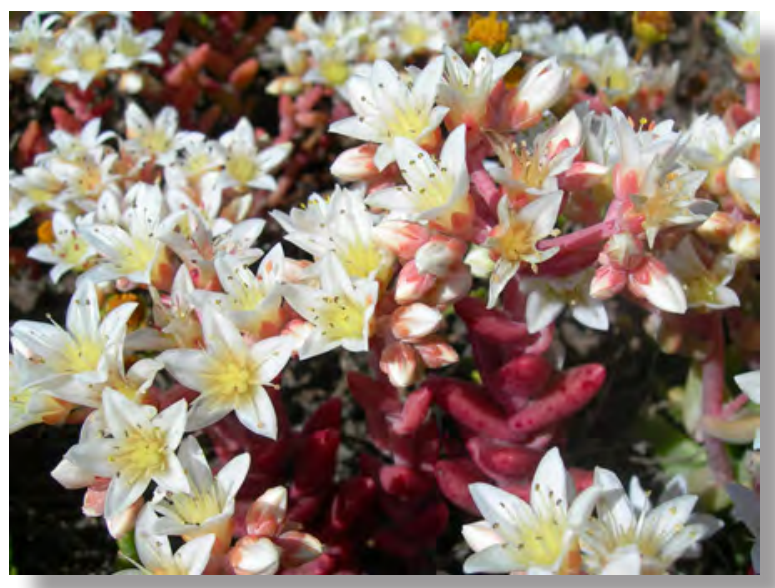

Santa Cruz Island live-forever (Dudleya nesiotica)

Scientific Investigations Report 2009-5264 

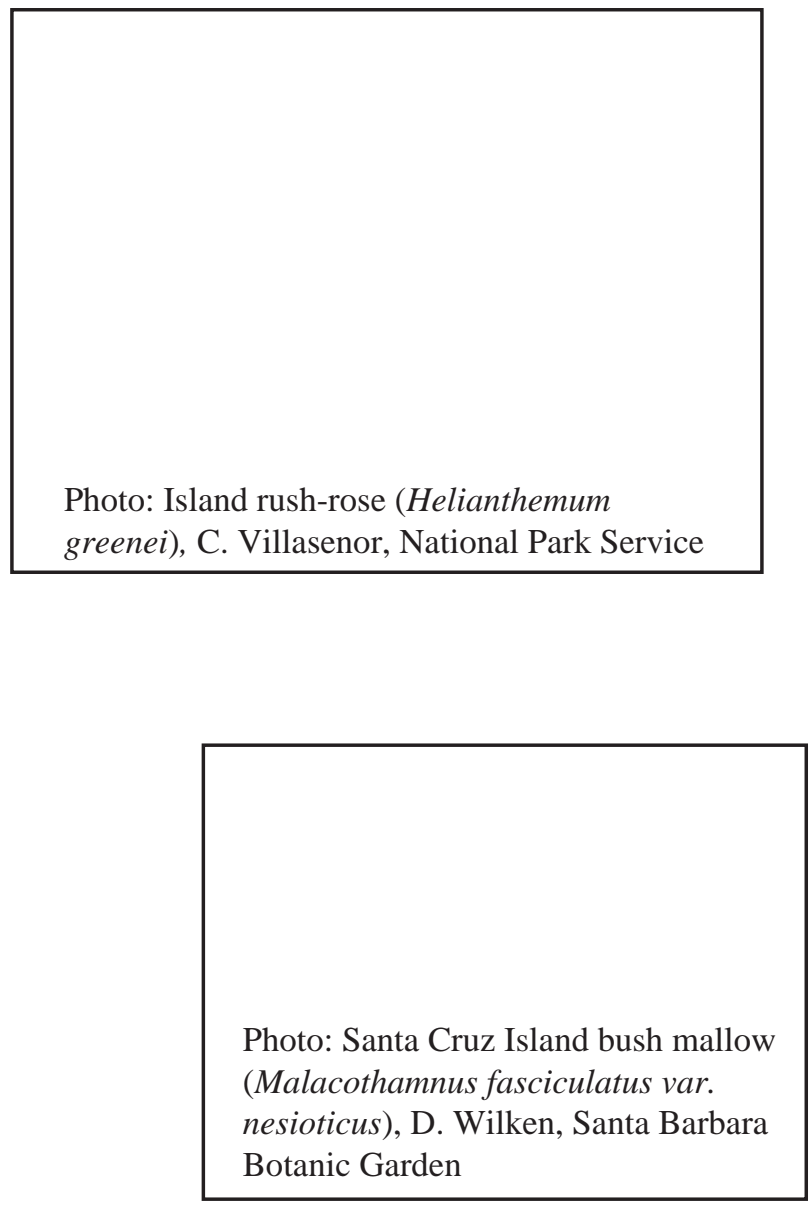

Photo: Santa Cruz Island live-forever (Dudleya nesiotica),K. Chess, U.S. Geological Survey 


\section{Field Surveys of Rare Plants on Santa Cruz Island, California, 2003-2006: Historical Records and Current Distributions}

By A. Kathryn McEachern, Katherine A. Chess, and Kenneth G. Niessen

In cooperation with La Luna Biological Consulting

Scientific Investigations Report 2009-5264 


\title{
U.S. Department of the Interior \\ KEN SALAZAR, Secretary
}

\section{U.S. Geological Survey \\ Marcia K. McNutt, Director}

\section{U.S. Geological Survey, Reston, Virginia: 2010}

\author{
For more information on the USGS — the Federal source for science about the Earth, its natural and living resources, \\ natural hazards, and the environment, visit http://www.usgs.gov or call 1-888-ASK-USGS \\ For an overview of USGS information products, including maps, imagery, and publications, \\ visit http://www.usgs.gov/pubprod \\ To order this and other USGS information products, visit http://store.usgs.gov
}

Any use of trade, product, or firm names is for descriptive purposes only and does not imply endorsement by the U.S. Government.

Although this report is in the public domain, permission must be secured from the individual copyright owners to reproduce any copyrighted materials contained within this report.

Suggested citation:

McEachern, A.K., Chess, K.A., and Niessen, K.G., 2010, Field surveys of rare plants on Santa Cruz Island, California, 2003-2006: Historical records and current distributions: U.S. Geological Survey Scientific Investigations Report $2009-5264,34 p$ 


\section{Contents}

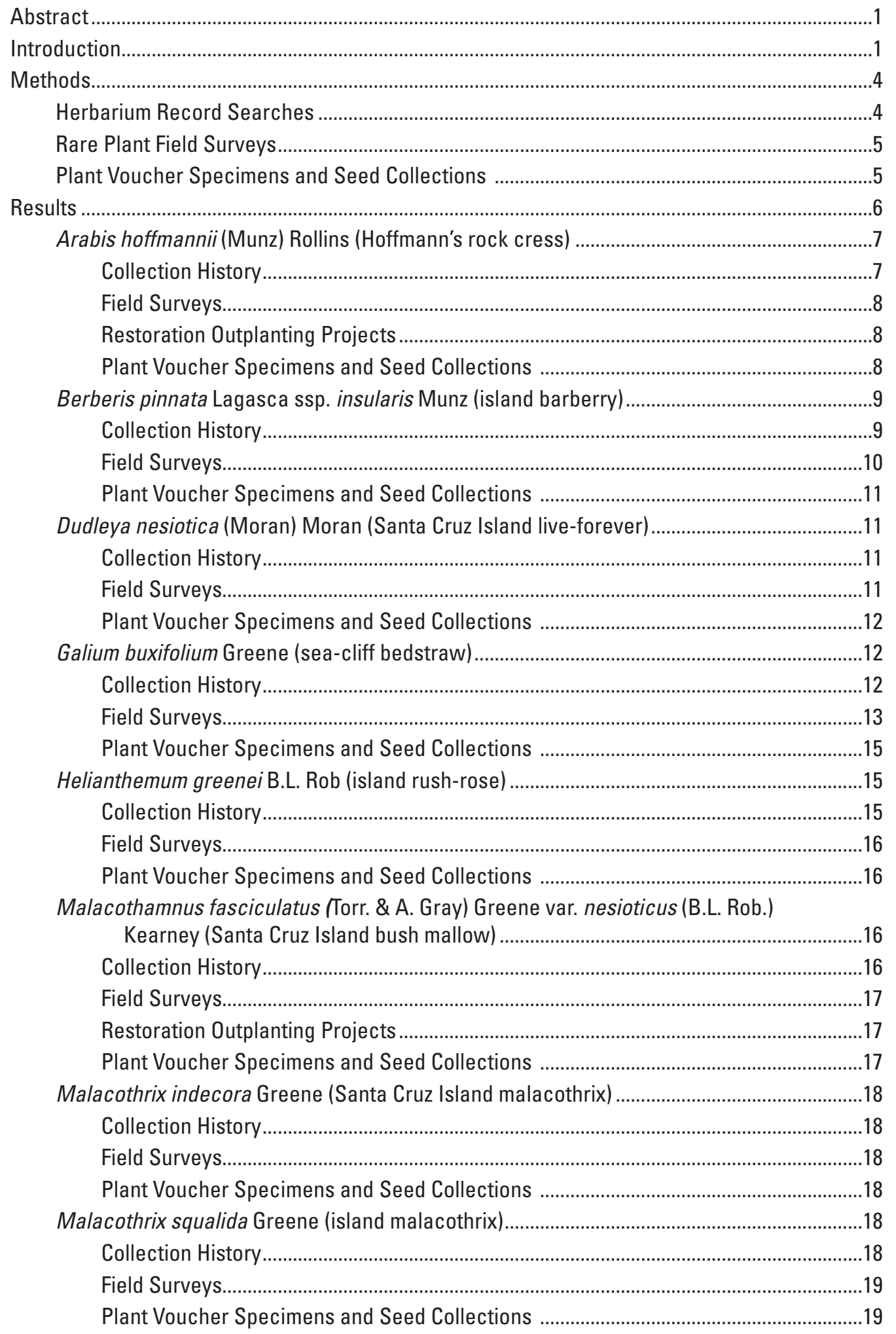


Thysanocarpus conchuliferus Greene (Santa Cruz Island lacepod) .....................................19

Collection History....................................................................................................

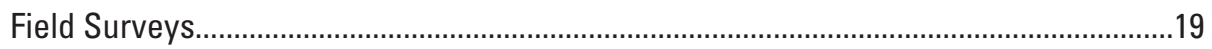

Plant Voucher Specimens and Seed Collections Details.................................................21

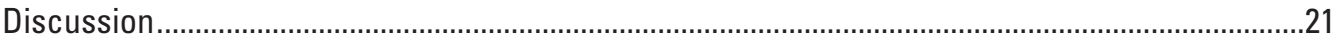

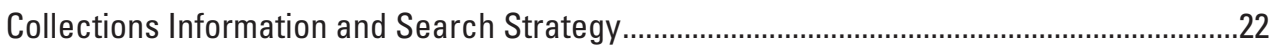

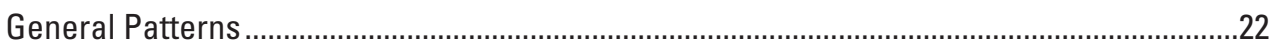

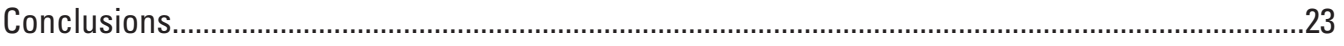

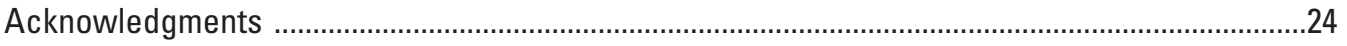

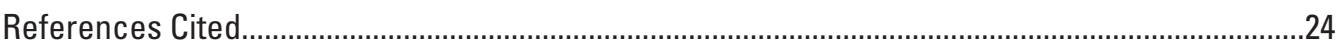

Appendix A. Historic and Current Occurrences of Federally Listed Plants on

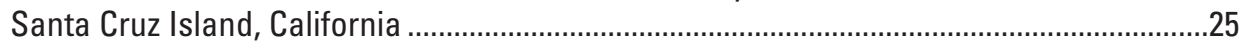

\section{Figures}

A-1.-A-9. Map showing:

1. Land ownership and place names, Santa Cruz Island, California

A-1. Arabis hoffmannii (Hoffmann's rock-cress) USGS identified sites on

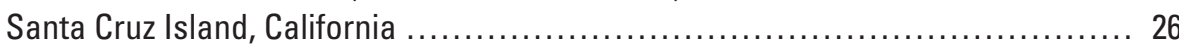

A-2. Berberis pinnata ssp. insularis (island barberry) USGS identified

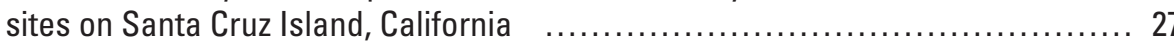

A-3. Dudleya nesiotica (Santa Cruz Island live-forever) and hybrids USGS identified sites on Santa Cruz Island, California ........................ 28

A-4. Galium buxifolium (sea-cliff bedstraw) USGS identified sites on

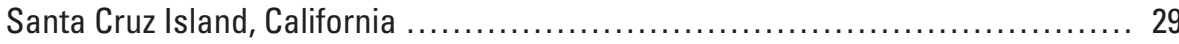

A-5. Helianthemum greenei (island rush-rose) Santa Cruz Island, California ...... 30 A-6. Malacothamnus fasiculatus var. nesioticus (Santa Cruz Island bush malllow) USGS identified sites on Santa Cruz Island, California $\ldots \ldots \ldots \ldots \ldots \ldots . \ldots 31$

A-7. Malacothrix indecora (Santa Cruz Island malacothrix) USGS identified

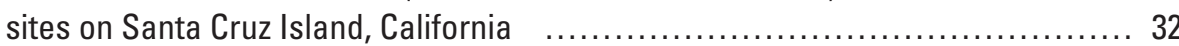

A-8. Malacothrix squalida (island malacothrix) USGS identified sites on Santa Cruz Island, California ............................................. 33

A-9. Thysanocarpus conchuliferus (Santa Cruz Island lacepod) USGS identified sites on Santa Cruz Island, California

\section{Tables}

1. Status, life histories, and known numbers of occurrences of federally listed plants of Santa Cruz Island, California.

2. U.S. Geological Survey rare plant research on Santa Cruz Island, California, 2003-2006

3. Methods for directed searches for rare plants on Santa Cruz Island, California

4. Methods for collecting seeds from federally listed plants of Santa Cruz Island, California 
5. Results of the surveys of Arabis hoffmannii populations, the approximate area they occupy, and the total number in each population on Santa Cruz Island, California, 2004-2006.

6. Arabis hoffmannii fruits, seeds, and voucher specimens collected during 2004-2006, Santa Cruz Island, California

7. Results of the surveys of Berberis pinnata ssp. insularis plants, the approximate area they occupy, and total number in each population on Santa Cruz Island, California, 2005-2006.

8. Berberis pinnata ssp. insularis fruits, root cuttings and voucher specimens collected in 2006, Santa Cruz Island, California

9. Dudleya nesiotica and Dudleya nesiotica $\times$ D. greenei survey results from Santa Cruz Island, California, 2005-2006: approximate area occupied and total plants in populations

10. Dudleya nesiotica and D. nesiotica $\times$ D. greenei fruits, live cuttings, and voucher specimens collected by Stephen McCabe, University of California Santa Cruz during 2004-2006, Santa Cruz Island, California

11. Results of the surveys of Galium buxifolium populations, the approximate area they occupy, and the total number in each population on Santa Cruz Island, California, 2004-2006

12. Galium buxifolium seeds and voucher specimens collected during 2004-2006, Santa Cruz Island, California

13. New populations documented for Helianthemum greenei, the approximate area they occupy, and the total number in each population on Santa Cruz Island, California, 2001-2006

14. Helianthemum greenei voucher specimens collected 2004-2006, Santa Cruz Island, California 16

15. Results of the surveys of Malacothamnus. fasciculatus var. nesioticus populations, the approximate area they occupy, and the total number in each population on Santa Cruz Island, California, 2004-2006

16. Malacothamnus fasciculatus var. nesioticus seeds and voucher specimens collected during 2004-2006, Santa Cruz Island, California

17. Results of the surveys of Malacothrix indecora populations, the approximate area they occupy, and the total number in each population on Santa Cruz Island, California, 2003-2006

18. Malacothrix indecora seeds and voucher specimens collected during 2006, Santa Cruz Island, California

19. Results of the surveys of Malacothrix squalida populations, the approximate area they occupy, and the total number in each population on Santa Cruz Island, California, 2006

20. Results of the surveys of Thysanocarpus conchuliferus populations, the approximate area they occupy, and the total number in each population on Santa Cruz Island, California, 2003-2006

21. Thysanocarpus conchuliferus seeds and voucher specimens collected 2004-2006, Santa Cruz Island, California 
This page intentionally left blank. 


\title{
Field Surveys of Rare Plants on Santa Cruz Island, California, 2003-2006: Historical Records and Current Distributions
}

\author{
By A. Kathryn McEachern, Katherine A. Chess, and Kenneth G. Niessen
}

Abstract

Santa Cruz Island is the largest of the northern Channel Islands located off the coast of California. It is owned and managed as a conservation reserve by The Nature Conservancy and the Channel Islands National Park. The island is home to nine plant taxa listed in 1997 as threatened or endangered under the federal Endangered Species Act, because of declines related to nearly 150 years of ranching on the island. Feral livestock were removed from the island as a major conservation step, which was part of a program completed in early 2007 with the eradication of pigs and turkeys. For the first time in more than a century, the rare plants of Santa Cruz Island have a chance to recover in the wild. This study provides survey information and living plant materials needed for recovery management of the listed taxa. We developed a database containing information about historical collections of the nine taxa and used it to plan a survey strategy. Our objectives were to relocate as many of the previously known populations as possible, with emphasis on documenting sites not visited in several decades, sites that were poorly documented in the historical record, and sites spanning the range of environmental conditions inhabited by the taxa. From 2003 through 2006, we searched for and found 39 populations of the taxa, indicating that nearly 80 percent of the populations known earlier in the 1900s still existed. Most populations are small and isolated, occupying native-dominated habitat patches in a highly fragmented and invaded landscape; they are still at risk of declining through population losses. Most are not expanding beyond the edges of their habitat patches. However, most taxa appeared to have good seed production and a range of size classes in populations, indicating a good capacity for plant recruitment and population growth in these restricted sites. For these taxa, seed collection and outplanting might be a good strategy to increase numbers of populations for species recovery. Several taxa have particular problems evidenced by lack of fruit set, very small population sizes, or unstable habitats. We collected seeds of all but two taxa for seed banking, and live cuttings of two clonal shrubs for cultivation at the Santa Barbara Botanic Garden. The survey data, seeds and cuttings provide a baseline and a foundation for planning, conducting, and tracking recovery of the nine federally listed plant taxa of Santa Cruz Island.

\section{Introduction}

Santa Cruz Island is one of the largest islands, $249 \mathrm{~km}^{2}$ $\left(96 \mathrm{mi}^{2}\right)$, in the northern Channel Islands group. Like the other islands and parts of the nearby California mainland, Santa Cruz Island was a sheep and cattle ranch; wool, hides, tallow, and meat were produced from the mid-1800s until the late 20th century (Junak and others, 1995). In the ranching heyday of the early 1900s, wine and table grapes were also produced for export to the mainland; hay and produce were grown for ranch use. Unlike many mainland areas, the islands are now managed for conservation; ranch production has halted and the feral livestock have been removed. Santa Cruz Island is owned and managed cooperatively by Channel Islands National Park (National Park Service [NPS]) and The Nature Conservancy (TNC) (fig. 1). Sheep and cattle were removed by TNC in 1986 on the westernmost 90 percent of the island, and sheep were removed by NPS from the remaining eastern part of the island in 1999. Both agencies cooperated on a feral pig removal project that started in 2005 and ended with removing the last pig in early 2007. Introduced turkeys were removed in 2007; California quail still remain on the island. 


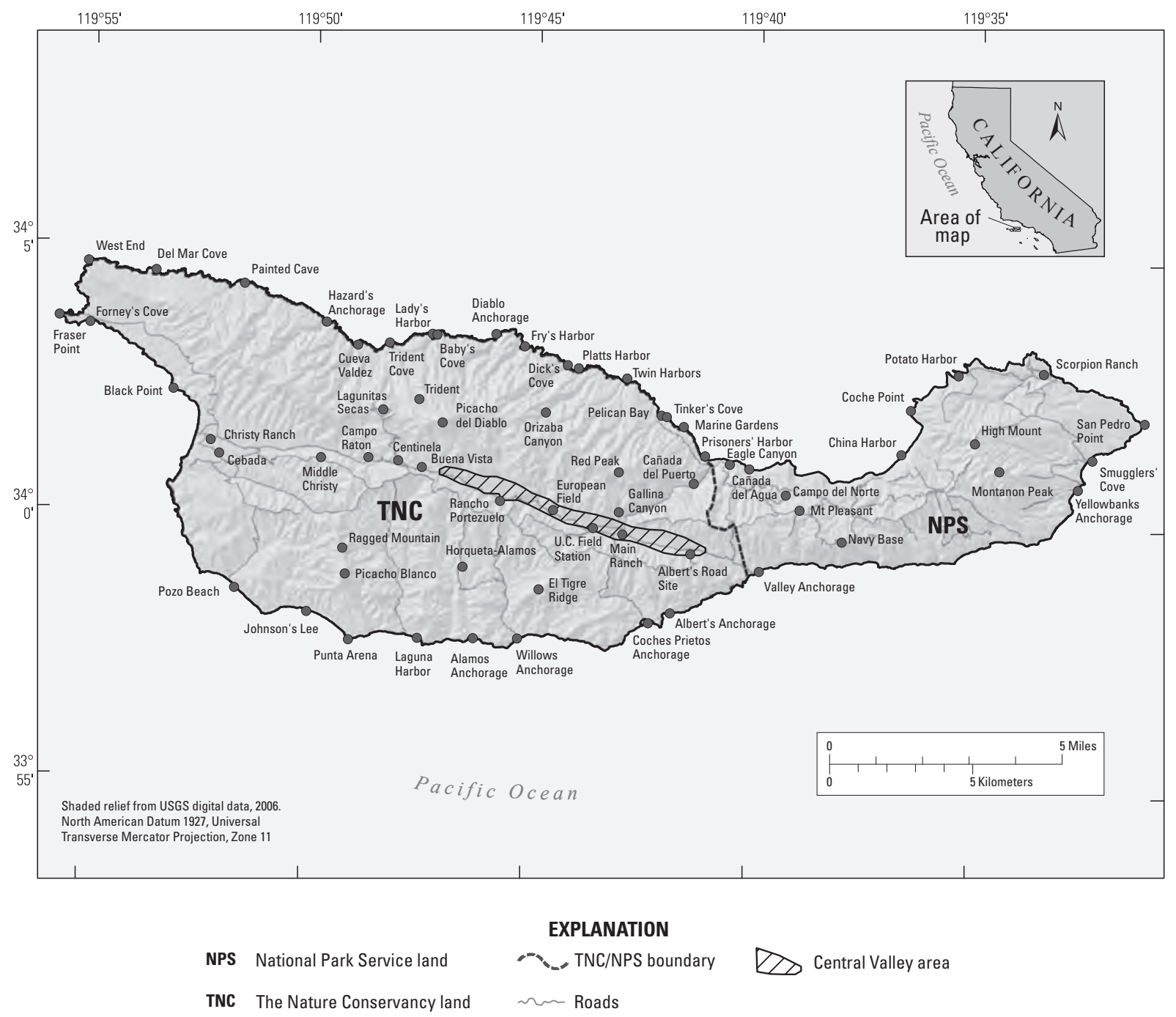

Figure 1. Land ownership and place names, Santa Cruz Island, California. 
Ranching is a consumptive use of the land, with farreaching effects on native plants and animals. During the early days of ranching, Santa Cruz Island appeared to be a self-sustaining ranch system, with ample native vegetation and supplemental hay production to support the livestock. However, large grazing animals are not native to the island and the plants are not adapted to sustained grazing pressure. Thus, by the late $1800 \mathrm{~s}$, there were signs that the island was becoming overstocked. Ranch managers became aware of this as they saw livestock yields, vegetation cover, and productivity decline, and non-palatable plants like pricklypear cactus increase (Junak and others, 1995). In ecological terms, the livestock numbers were reaching and surpassing the island's ecological carrying capacity. Attempts were made by ranchers to reduce the numbers of sheep and pigs, especially during droughts of the 1920s and 1940s, but generally numbers fluctuated upwards following eradication episodes. At its peak in the late-1800s, the ranch fielded up to 100,000 sheep (Junak and others, 1995). Most of the animals were allowed free range, although they were brought into corrals annually for shearing or slaughter. In the mid-1900s, the ranch was converted to a cattle operation to ease pressure on the vegetation. However, sheep proved nearly impossible to round up, and they were left to range freely, mainly in the most inaccessible parts of the island.

Ranching effects on the native vegetation were profound, on Santa Cruz Island as well as on the other Channel Islands. The once continuous canopies of chaparral, coastal scrub, and island woodland were segregated into fragments, with compacted animal trails and open eroded areas in between. Some plant communities are missing from large tracts of land where they were replaced by exotic annual grasses, perennial stands of fennel (Foeniculum vulgare), or barren landscapes. Notable among these are the coastal sage and coastal bluff scrub plant communities, coast live oak stands in the Central Valley, and the lost bishop pine woodland of the Sierra Blanca ridge. Riparian vegetation was nearly eliminated islandwide, correlated with the loss of water storage capacity in the stream systems. Certain rare plant taxa once observed to be more widespread have been reduced to a few populations at sites often inaccessible to feral animals. These changes in the vegetation represent fundamental changes in plant and animal habitats, and in the way the vegetation-soil-water system works on the island.

Removing feral animals is one of the most far-reaching management actions yet taken by NPS and TNC for island conservation. In fact, scientists have observed some vegetation recovery since removing sheep on both the western and eastern parts of the island. Some plant communities appear to respond more quickly than others, and vegetation on the more mesic, north-facing slopes shows signs of the fastest recovery. Overall, recovery appears fastest in years of high rainfall (L. Laughrin, University of California Santa Cruz Island Reserve, oral commun., 1994).

We conducted an island-wide plot-based vegetation study during 2002-2003 (U.S. Geological Survey [USGS] unpublished), designed to provide information on the condition of the plant communities after sheep removal but before pig eradication. This baseline study showed that the island is recovering since sheep removal and that the pace of recovery was slowed by activities of the remaining pigs. Almost all areas have been invaded by exotic plants, signs of past pig disturbance is nearly everywhere, soils are exposed with little seed bed development on steep southern slopes, fragmentation has reduced the average size of many stands of native vegetation to less than one hectare (approximately 2 acres), and many communities lack the internal undergrowth and branching structure of undisturbed native stands.

However, there is new understory growth in some sites where shrub canopies have reconnected, particularly on north-facing slopes where soils are deepest and can retain moisture. Some isolated chaparral scrub stands in protected places on the south side of the island have a fringe of small plants near the fogdrip line, where young sprouts and seedlings have been able to establish in the absence of sheep browsing. With pig removal, the island will have a chance to recover.

The U.S. Fish and Wildlife Service (USFWS) listed nine Santa Cruz Island plant taxa as endangered or threatened (table 1) in 1997 as the result of habitat alteration, low numbers of populations, demographic decline within populations, and the continued presence of feral animals (U.S. Fish and Wildlife Service, 1997). A few of these plants may be able to rebound without more active management as habitats recover following pig removal. However, we know little about the "raw materials" available in the field for conservation of most of these taxa and thus cannot predict the best tactics for ensuring recovery.

Table 1. Status, life histories, and known numbers of occurrences of federally listed plants of Santa Cruz Island, California.

\begin{tabular}{|c|c|c|c|}
\hline Taxon & Status & $\begin{array}{l}\text { Life } \\
\text { history }\end{array}$ & $\begin{array}{c}\text { Santa Cruz Island } \\
\text { occurrences }{ }^{1}\end{array}$ \\
\hline Arabis hoffmannii & Endangered & Perennial herb & 5 \\
\hline $\begin{array}{l}\text { Berberis pinnata ssp. } \\
\text { insularis }\end{array}$ & Endangered & Shrub & 7 \\
\hline Dudleya nesiotica & Threatened & Succulent & 3 \\
\hline Galium buxifolium & Endangered & Shrub & 21 \\
\hline Helianthemum greenei & Threatened & Small shrub & ${ }^{2} 22$ \\
\hline $\begin{array}{l}\text { Malacothamnus } \\
\text { fasciculatus var. } \\
\text { nesioticus }\end{array}$ & Endangered & Shrub & 4 \\
\hline Malacothrix indecora & Endangered & Annual herb & 3 \\
\hline Malacothrix squalida & Endangered & Annual herb & 2 \\
\hline $\begin{array}{l}\text { Thysanocarpus } \\
\text { conchuliferus }\end{array}$ & Endangered & Annual herb & 23 \\
\hline
\end{tabular}

${ }^{1}$ Documented by authoritative records; includes new populations found 2003-2006.

${ }^{2}$ Sites documented from 2001-2006; older sites too poorly documented to identify. 
In 2003, we began a conservation and recovery research program for the nine listed taxa. Our program includes compilation of herbarium records, field surveys, and demography monitoring to determine population status and trends; field and greenhouse experiments to identify techniques for population conservation; and outplanting trials on the island. This work has been funded by USGS, grants from NPS and TNC, in-kind salary contributions from the Santa Barbara Botanic Garden, and in-kind logistical support from the University of California Santa Cruz Island Reserve.

\section{Methods}

Our ultimate goals are to develop conservation tools for the listed plant taxa of Santa Cruz Island and to document how natural populations recover following pig removal. Therefore, our research method follows a logical progression of herbarium records research and field survey followed by demographic monitoring and life history research for each taxon. Steps include (1) compile herbarium records and develop a search strategy for each taxon, (2) find previously collected or documented populations and assess their status, (3) conduct demographic studies on a select few populations to investigate trends and identify mechanisms that may hinder recovery, (4) collect seeds and tissue for banking and cultivation in off-site living collections, (5) collect plant voucher specimens of newly discovered and under-collected plant populations, (6) conduct seed germination and other life history research, and (7) for several of the most at-risk plants, conduct experimental field outplanting trials to develop new populations.

This report presents results of the herbarium searches and field surveys, including details of plant voucher collections and seed collections. Demography monitoring, breeding system and germination results, and outplanting experiments are described in separate reports. The general methodology for herbarium searches and field surveys is described in this section. Specific methods and results are further elaborated in the following sections organized by plant taxon. Table 2 shows USGS research activities for the Santa Cruz Island taxa during 2003-2006.

\section{Herbarium Record Searches}

As a fundamental part of this research, we developed a database of historical and current rare plant locations and associated attributes, housed on the Channel Islands National Park local area network. The spatial data are accessible as shapefiles in the "sc_plants" GIS directory. Corresponding data on attributes such as plant numbers, population and habitat conditions, collector information, and survey methods and dates are archived in the LandVeg "PlantSightings" database. The two databases can be linked or joined within the ArcGIS environment to query and display data by attributes. The location data are used as overlays in the geographic information system to model potential habitats for further surveys, ecological analyses, and restoration sites. This is a "live" database used by USGS and NPS to organize past and current survey knowledge, plan management activities, and document current research and management activities.

Table 2. U.S. Geological Survey rare plant research on Santa Cruz Island, California, 2003-2006.

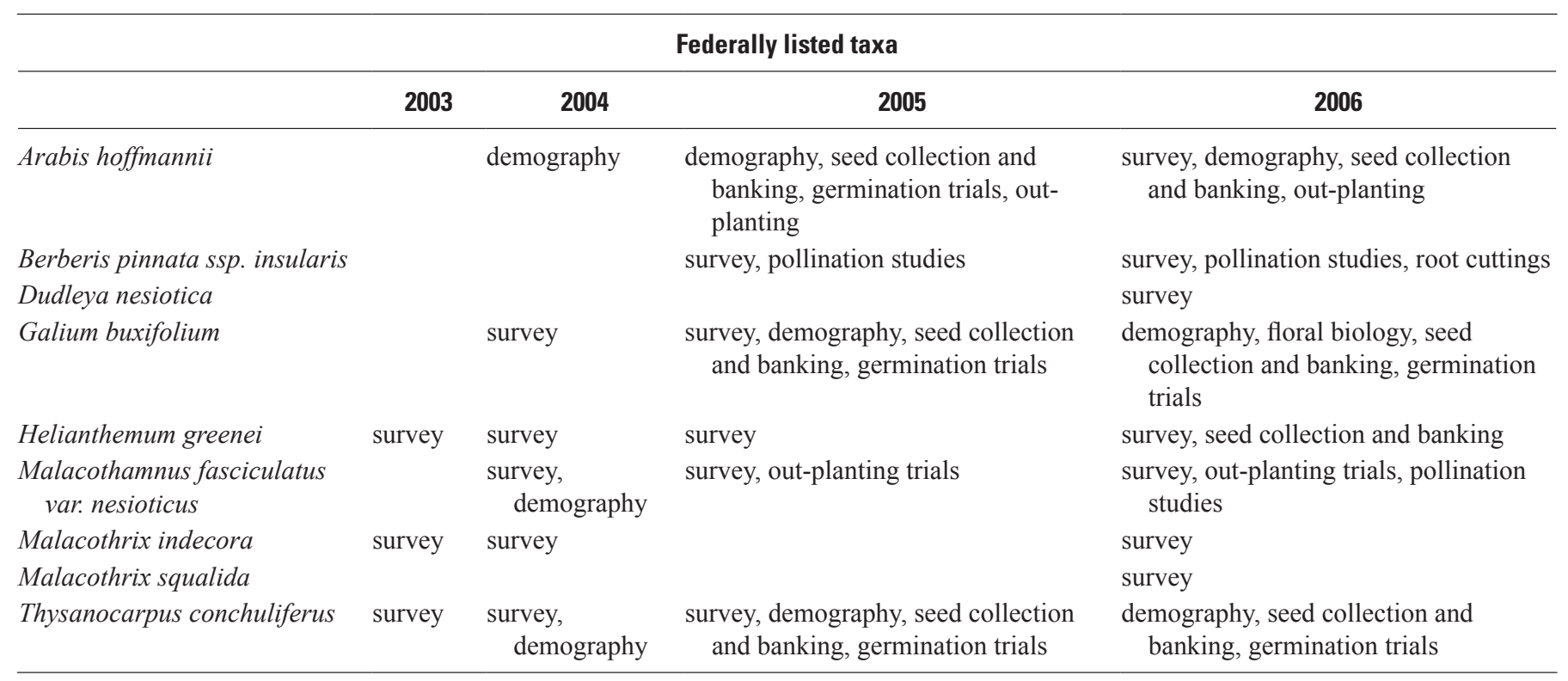


About two-thirds of the "Plant Sightings" database records for Santa Cruz Island have location information and associated field notes compiled from a 1978-1979 Santa Cruz Island rare plant survey (Hochberg and others, 1980) and from NPS, Santa Barbara Botanic Garden (SBBG), and California Natural Diversity Database (CNDDB) files. In the late 1990s, label data were added from herbaria containing Channel Islands collections, including the Rancho Santa Ana, the Jepson, the University of California (UC) Berkeley, the U.C. Santa Barbara, and the U.C. Santa Cruz herbaria. From 2005 to 2007 , these records were cross-referenced with information on Santa Cruz Island collections from the on-line herbarium database search-engines of the Consortium for California Herbaria (University of California, 2007; http://ucjeps. berkeley.edu/consortium/). Finally, the database contains results from our 2003-2006 surveys, including relocations of known populations, failures to find plants at previously documented locations, and new finds. Collections history from this database is summarized briefly in this report.

\section{Rare Plant Field Surveys}

Santa Cruz Island is home to an estimated 650 plant taxa; 26 percent of those are not native to the island (S. Junak and others, 1995). Among the natives are 45 plants that are endemic to the Channel Islands, and 8 of those are "restricted endemics" found only on Santa Cruz Island. The earliest botanical surveys were made at the end of the 1800s. In the $20^{\text {th }}$ century, an extensive plant voucher collection was built at the Santa Barbara Botanic Garden, and in 1995, S. Junak and others wrote an authoritative flora of the island. These surveys document the rarest plants of the island only sporadically. In 1980, shortly before sheep removal, Hochberg and others published results of island-wide searches for those plants considered by local botanists to be most rare or at risk.

The historical collection and survey information comes from many sources, ranging from field notes and herbarium label data to published reports. Most of the records collected before the 1960s provide at best only general information on plant numbers, habitat attributes, and locations. Consequently, it is impossible to know exactly where some collections were made and what the population size and health were at the time. Often, we were able to re-find a population, but whether it has grown or declined, or whether the habitat has improved, is largely unknown. Advances in georeferencing have made recent records more accurate, but our ability to positively relocate some collection sites is still limited by the lack of detailed accompanying information. In many instances, we developed field search strategies based on our knowledge of plant habitat requirements coupled with general location information that was available, such as "Lady's Canyon...". In a few cases, populations were known and were described and visited several times over several decades, enabling us to construct a clear population record from the early 1900s until present.
Goals for the field surveys were to visit most of the known locations to record population and habitat conditions, count or estimate numbers of plants and areal population extent, describe the habitat conditions, collect voucher specimens, and obtain seed for banking and recovery research. Time and funding did not permit a systematic survey of the entire island for these taxa; rather our goal was to verify whether known populations still existed and establish their status. Survey results were used to select demography monitoring sites for populations of several taxa, for which we need life-history and trend data to plan effective conservation (Pavlik, 1994). California Natural Diversity Database (CNDDB) community survey forms (California Department of Fish and Game, 2006) were completed for each population visited, and that information was entered into the "PlantSightings" database. Table 3 outlines the methodology for the rare plant surveys. Demography study methods and results will be presented separately. Individual survey details are given for each taxon in the species-specific sections that follow.

\section{Plant Voucher Specimens and Seed Collections}

McEachern and Wilken (Santa Barbara Botanic Garden) received National Park Service Natural Resource Protection Program (NRPP) funding for field and laboratory studies for 2005-2006 to investigate specific life-history attributes and begin outplanting research for several listed Santa Cruz Island plants (McEachern and Wilken, 2004). This funding supplemented the field survey work, providing for plant voucher and seed collections. Voucher specimens were collected from localities where plants had not previously been collected or had not been collected in several decades. Collections were only made where there were sufficient plants to collect without jeopardizing the population. Vouchers were prepared at the USGS Channel Islands Field Station and deposited in the SBBG. Seed, tissue and voucher collection is permitted under United States Fish and Wildlife Service Research and Recovery Permit \# TE-044846 (U.S. Fish and Wildlife Service, 2000a, 2006).

The SBBG has seed from some Santa Cruz Island rare plant populations, and they have plants of some taxa in cultivation from which they can harvest seed. Therefore, the seed collection strategy was to collect from taxa and populations lacking an off-site seed bank if seed production was sufficiently large enough to sustain collection (Guerrant and others,2004). Methods for collecting and banking seeds follow policies and guidelines of the Center for Plant Conservation and SBBG (table 4). Seeds are banked at SBBG and, at the discretion of SBBG, at the National Seed Storage Laboratory in Ft. Collins, Colorado. Because Berberis pinnata ssp. insularis rarely produces fruit in the wild and is therefore poorly represented in off-site living collections, we collected root cuttings also from two individuals for conservation at the SBBG. 
Table 3. Methods for directed searches for rare plants on Santa Cruz Island, California.

1. Update rare plant distribution and abundance information in U.S. Geological Survey (USGS) Channel Islands Field Station and Channel Islands National Park ArcGIS - MSAccess database ("PlantSightings") with new records from USGS, National Park Service, and Santa Barbara Botanic Garden, and on-line herbarium records searches.

2. Develop search strategy - map known locations and prioritize based on time since last survey and relative rarity of the taxon, outline additional areas with potential habitat that have not been surveyed in at least the last 10 years, develop a 4-year survey schedule.

3. Assemble teams of 2-6 staff and volunteer botanists for surveys late February to early July, 2003-2006.

4. Conduct surveys:

a. Search areas outlined for survey, map areas surveyed using GPS, aerial photographs, and topographic maps.

b. Map sites found and sites searched but not found using GPS, aerial photographs, and topographic maps.

c. Estimate area occupied.

d. Describe how to get to the location.

e. Count or estimate numbers of individuals if occurrence is small; sample randomly placed belt transects or plots for density if population is large.

f. Record population size structure (classes: seedling, small juvenile plant; medium and large plants).

g. Record phenology: percentage of population flowering, fruiting and dead.

h. Record habitat: aspect, slope, substrate, elevation, conditions of habitat/habitat quality for the target species, microhabitat occupied by the target species (use California Natural Diversity Database field form for phenological and habitat observations [www.dfg.ca.gov/whdab/pdfs/natspec.pdf]).

5. Download data from GPS and palmtops into ArcView/ArcGIS, MSAccess and MSExcel databases.

6. $\quad$ Produce report showing survey results by species surveyed.

Table 4. Methods for collecting seeds from federally listed plants of Santa Cruz Island, California.

1. Identify sites for seed collection on the basis of past collection history, availability of living collections, population size and fecundity, and accessibility.

2. Survey to determine the best phenological time to collect them.

3. Collect no more than $10 \%$ of the current year's production of seeds or fruits at each population site - less if the population is small or has low fruit set.

4. Put seeds in one individual coin-sized paper or glassine envelopes for each mother plant. Label each envelope with taxon, date, site, collector, and mother plant identifier.

5. Record collection information in an archival database.

6. Take the envelopes to the Santa Barbara Botanic Garden within several days of the collection date, where the seeds are dried in desiccation chambers, and then frozen for banking.

\section{Results}

Table 2 shows USGS research activities for each of the Federally listed taxa of Santa Cruz Island from 2003 through 2006 for several related projects. This Results section reviews the herbarium search, field survey, plant voucher collection, and seed and cutting collection results for each taxon. The historical collections are described for each taxon, and USGS survey data are presented cumulatively from 2003 through 2006. Appendix A, figures A-1 through A-9, show known historic sites and USGS survey results for each taxon; sites where we conduct additional research are also indicated. Taxonomy and place names (fig. 1) are those reported by Junak and others (1995). 


\section{Arabis hoffmannii (Munz) Rollins (Hoffmann's rock cress)}

\section{Collection History}

Arabis hoffmannii, endemic to at least two of the Channel Islands, is a short-lived perennial herb that is one of two listed taxa on Santa Cruz Island in the Brassicaceae family. It has been called Arabis maxima var. hoffmannii. Recent taxonomic changes put this species in the genus Boechera (B. hoffmannii; Al-Shehbaz and others, 2006). During its first one to three years, A. hoffmannii grows as a vegetative rosette that can reach nearly $0.5 \mathrm{~m}(1.6 \mathrm{ft})$ tall. Upon maturity, it develops one or more flower stalks, each producing tens to hundreds of fruits (Wilken, 1996; McEachern and others, 1997). Although the species is generally thought to be monocarpic, we have observed some robust plants to flower for up to two years in a row before dying.

In addition to Santa Cruz Island, A. hoffmannii may grow on Santa Rosa Island and West Anacapa Island, two other Channel Islands. A. hoffmannii was documented on Santa Rosa Island in 1930 (Junak and others, 1995), was for a time believed to be extirpated, and was not seen again until 1996, when botanists rediscovered this plant on a sandstone ledge in Lobo Canyon (McEachern and others, 1997). This site has been monitored since then; a general decrease in plant counts was documented, and plants have not been seen at this location since 2002. In addition, there is a record for A. hoffmannii from West Anacapa Island observed in 1941 reported by CNDDB, but there is no known specimen and the species has not been found there despite several searches.
A. hoffmannii was first collected on Santa Cruz Island in 1888 by T.S. Brandegee at an unspecified location (U.S. Fish and Wildlife Service, 1997). By the 1970s, A. hoffmannii was believed to be extirpated from Santa Cruz Island (Hochberg and others, 1980). In March 1985, however, it was independently rediscovered by two separate parties in different locations. Four Santa Cruz Island A. hoffmannii populations were known when we began our surveys: two on the north side of the island and two in the Central Valley (table 5; fig. A-1). We discovered a fifth population in 2004, on the north ridge of the island. They are discussed here in the order of their discovery.

The type locality, or source of the specimen used for the published taxonomic species description, was on the bluffs of the north shore at Platts Harbor (historically called "Dick's" or "Dix Harbor") (Site 1, figs. 1, A-1, table 5). Plants were first collected from this site by Ralph Hoffmann in 1932, and plants were seen there in 1990 by S. Junak and Steven McCabe (S. McCabe, University of California Santa Cruz, oral commun., 2006).

The plants at the site located along the Albert's Road (Site 2, fig. A-1) were probably first discovered in 1950 by Reid Moran (Wilken 1996), who described them as "several plants together in chaparral on north-facing slope, Ranch Valley, Santa Cruz Island." The site has been called the Stanton Ranch site, since it is only $2 \mathrm{~km}(1.2 \mathrm{mi})$ east of the Main Ranch (formerly the Stanton Ranch [Junak and others, 1995]).

Table 5. Results of the surveys of Arabis hoffmannii populations, the approximate area they occupy, and the total number in each population on Santa Cruz Island, California, 2004-2006.

$\left[\mathrm{m}^{2}\right.$, square meter]

\begin{tabular}{|c|c|c|c|c|c|c|}
\hline \multirow{2}{*}{$\begin{array}{c}\text { Site No. } \\
\text { (See fig. A-1 } \\
\text { for location) }\end{array}$} & \multirow{2}{*}{ Date } & \multirow{2}{*}{$\begin{array}{c}\text { Site } \\
\text { name }\end{array}$} & \multirow{2}{*}{$\begin{array}{c}\text { Area } \\
\left(\mathrm{m}^{2}\right)\end{array}$} & \multicolumn{3}{|c|}{ Plant counts } \\
\hline & & & & 2004 & 2005 & 2006 \\
\hline 1 & $05-05-06$ & Platts Harbor bluff & 200 & not surveyed & not surveyed & 19 \\
\hline 2 & $\begin{array}{l}05-25-04 \\
04-17-05 \\
06-19-06\end{array}$ & $\begin{array}{l}\text { Stanton Ranch } \\
\quad \text { (now Main Ranch) }{ }^{1}\end{array}$ & 6 & 33 & 81 & 138 \\
\hline 3 & $05-05-06$ & Platts Canyon & unknown & not surveyed & not surveyed & surveyed, not found \\
\hline 4 & $\begin{array}{l}05-13-04 \\
04-16-05\end{array}$ & Centinela & 450 & not surveyed & ${ }^{2} 485$ & not surveyed \\
\hline 5 & $\begin{array}{l}04-18-04 \\
04-14-05\end{array}$ & Trident-Lady's Ridge 1,3 & 2,400 & 125 & 143 & 140 \\
\hline
\end{tabular}

\footnotetext{
${ }^{1}$ Demographic monitoring site. Now called Main Ranch.

${ }^{2}$ Actual detailed count, but should be interpreted as a low estimate because not all occupied areas are accessible; boulders and crevices serve as habitat, so some individuals were likely out of view.

${ }^{3}$ A new population was discovered in 2004. The demography plot was established 2004. The plant count represents the number of plants in demography plots; the few plants outside the plots were not counted..
} 
In 1985, TNC biologists found $A$. hoffmannii plants while rappelling down a canyon wall in Platts Canyon (or a nearby canyon) (Site 3, fig. A-1) in search of Dudleya spp. (P. Schulyer, Catalina Island Conservancy, written commun., 1985). In the same year, S. Junak rediscovered plants at the "Centinela" location (Site 4, figs. 1, A-1) in the western part of the Central Valley (S. Junak, Santa Barbara Botanic Garden, oral commun., 2004).

\section{Field Surveys}

The Central Valley sites, "Centinela" and "Stanton (Main) Ranch," have been visited irregularly by various botanists over the past 20 years (figs. 1, A-1). However, the two north side populations near Platts Harbor had not been visited since 1985 and 1990, respectively, and the status of those populations was unknown in 2003. USGS botanists counted $A$. hoffmannii plants at the Stanton Ranch and Centinela sites in 2004 and initiated demographic monitoring at both sites in 2005. USGS botanists K. Chess and M. Barmann discovered a new, fifth population in 2004 on the north-south tending ridge between Trident and Lady's Canyons; demographic monitoring was initiated there in 2004. In June 2006, botanists rappelled down the cliff face to survey the Platts Harbor population and searched unsuccessfully for the Platts Canyon site.

Table 5 gives the approximate size of the area occupied and the number of plants counted at each naturally occurring site from 2004 through 2006, and figure A-1 shows the locations of these sites and of the demography sampling and outplanting sites. These numbers represent actual counts rather than estimates, but should be considered the minimum number present at the larger sites because some of the occupied habitat was not accessible.

The 19 plants seen in 2006 at the Platts Harbor bluff site should be considered a minimum because rappelling is the only way to access the site, and safety and protection of the fragile bluff environment makes it impossible to see all $A$. hoffmannii individuals. The coastal bluff scrub community on the bluff face at the site is dense, the vegetation is relatively tall, and substrate surfaces are difficult to see. Thus, seedlings and smaller vegetative $A$. hoffmannii were not seen, although they may well be present. Vegetation at this site is much more lush than at all other known sites. The site with the most similar vegetation is the oak understory habitat at the Trident Ridge site.
No A. hoffmannii plants were found within about $200 \mathrm{~m}$ (656 ft) of the coordinates estimated for the Platts Canyon population (P. Schulyer, Catalina Island Conservancy, written commun. [from field notes], 2004). Given the uncertain description of the location of the site, it may actually be located in an adjacent canyon. When the population was discovered by TNC botanists in 1985, they had to rappel to the plants, and we did not find any terrain near the estimated coordinates that would require rappelling. A larger area needs to be searched to find this population.

\section{Restoration Outplanting Projects}

Figure A-1 shows the locations of native populations along with four additional sites used for $A$. hoffmannii recovery outplanting experiments. We show the outplanted sites here to inform future surveys; these plantings are not at the sites of native populations. As part of an NPSNRPP funded recovery research project, we planted seeds and seedlings at three sites in the winter of 2005-2006. These research plantings are at the "Lagunitas Secas Road North", the "Lagunitas Secas Road South", and the "Alberts Road" sites. A second replicate set was planted at the three USGS research sites in 2006-2007; we continue to monitor these sites. Additionally, in 2004, NPS botanists planted $A$. hoffmannii seedlings grown from Centinela seed (provided by SBBG) in three approximately 7-m x 7-m pig-proof enclosures. The enclosures are located about $150 \mathrm{~m}(492 \mathrm{ft})$ west-southwest of the Centinela population and are spaced about $10 \mathrm{~m}(32.8 \mathrm{ft})$ apart. We watered and monitored this planting from 2004 to 2006; in 2007, no A. hoffmannii plants were present in these exclosures.

\section{Plant Voucher Specimens and Seed Collections}

Only one A. hoffmannii voucher specimen was collected during the study period (table 6). This specimen was collected on April 18, 2004, to document the newly discovered TridentLady's Ridge population. In June 2004, fruits were collected at Trident-Lady's Ridge. In June 2005, fruits were collected from both the Centinela and Trident-Lady's Ridge populations. Fruits were not collected from the Stanton site in 2004 or 2005 because the population there is very small. Fruits were collected from all three monitored natural populations in 2006.

Table 6. Arabis hoffmannii fruits, seeds, and voucher specimens collected during 2004-2006, Santa Cruz Island, California.

\begin{tabular}{|c|c|c|c|c|c|c|c|c|c|}
\hline \multirow{2}{*}{$\begin{array}{c}\text { Site } \\
\text { name }\end{array}$} & \multicolumn{3}{|c|}{ Total fruits } & \multicolumn{3}{|c|}{ Total seeds } & \multicolumn{3}{|c|}{ Voucher specimens } \\
\hline & 2004 & 2005 & 2006 & 2004 & 2005 & 2006 & 2004 & 2005 & 2006 \\
\hline Stanton Ranch & 0 & 0 & 10 & 0 & 0 & 1,200 & 0 & 0 & 0 \\
\hline Centinela & 0 & 20 & 10 & 0 & 2,565 & 1,363 & 0 & 0 & 0 \\
\hline Trident-Lady's Ridge & 13 & 18 & 15 & 2,093 & 3,173 & 2,090 & 1 & 0 & 0 \\
\hline
\end{tabular}


Seeds were counted per fruit for 2004-2006, pooled by population by year, and saved for seed banking and outplanting. Approximately 1,000 seeds (determined by weight) were deposited in the Santa Barbara Botanic Garden seed bank from each of the 2004 and 2005 Trident-Lady's Ridge collections, from the 2005 Centinela collection, and from the 2006 collections from all three sites. The remaining seeds were used in outplanting experiments on the island.

\section{Berberis pinnata Lagasca ssp. insularis Munz (island barberry)}

\section{Collection History}

Berberis pinnata ssp. insularis (previously Mahonia pinnata (Lag). Fedde ssp. insularis (Munz) J.B. Roof) is one of the rarest plants on the Channel Islands. It is now represented in the wild by only four recently relocated plants on Santa Cruz Island (appendix A, fig. A-2). B. pinnata ssp. insularis is a long-lived clonal shrub in the Berberidaceae family, inhabiting the shaded understory of mesic chaparral stands, mixed pine forest-chaparral, and riparian woodland on north-facing slopes and canyons. Because it sprouts from an underground root system, a single plant can consist of several stems spread over several square meters. This taxon was also known to grow on the West Anacapa islet and Santa Rosa Island. The only known Santa Rosa Island population was last collected in 1930, has not been relocated despite repeated searches, and is thought to be extirpated. The West Anacapa Island plant is known to have died recently (S. Junak, Santa Barbara Botanic Garden, oral commun., 2005).

Locality information recorded on herbarium labels is vague for most of the Santa Cruz Island vouchers collected before the 1980s. Two B. pinnata ssp. insularis locations are documented in Cañada Christy. The best known and most visited plant is located in Cañada Christy along the road near Campo Raton (Site 1, fig. A-2). It is presumed to be the same plant collected by Mason in 1927 and Hoffmann and Wolf in 1932 (Wilken, 1996). A cutting from this plant has been cultivated at the SBBG for several decades, and seeds were collected in the 1990s for off-site conservation at the SBBG (D. Wilken, Santa Barbara Botanic Garden, oral commun., 2006). The second Cañada Christy site is located upstream and east of Campo Raton in the upper Christy area, near the Centinela Grade (Site 1, fig. A-2). The date of discovery for the Upper Christy site is unclear, and field notes indicate that there may be several individual plants in the area. In the 1970s and 1980s, botanists located a few B. pinnata ssp. insularis plants in the Christy Pines in the Upper Christy region, (S. Junak, Santa Barbara Botanic Garden, oral commun., 2005), but location information was not recorded and it is unclear how many individual plants were found. In 1995, USFWS botanists hypothesized that as many as 10 plants have been reported in the upper Cañada Christy region ("Cañada de la Cuesta") (Rutherford and Thomas, 1995).

A third plant is known from lower Hazard's Canyon, above Hazard's Anchorage (Site 3, fig. A-2) on the north side of the island. This plant was discovered and collected in 1983 by P. Schuyler and seen in 1998 by NPS and SBBG botanists (S. Chaney, Channel Islands National Park, oral commun., 1998) A fourth B. pinnata ssp. insularis was discovered but not collected in 1984 by P. Schuyler in the east fork of Trident Canyon above Trident Cove (Site 5, fig. A-2).

In addition to the sites of these four known plants, there are three unverified or poorly documented B. pinnata ssp. insularis sites. There is a live specimen at the University of California Santa Cruz Arboretum, which apparently was collected in June 1979 within the Christy Pines region, somewhere between the Valley Road and the Ridge Road, upslope of the Campo Raton site (Site 6, fig. A-2). The second unverified locality (Site 4, fig. A-2) is for a voucher specimen now at the University of California Santa Cruz Island Reserve Field Station (UC Field Station) herbarium; it was collected by F. Roberts in 1984. This unverified locality was described as "2.3 km (1.4 mi) WNW Diablo Peak" in an area misidentified as "Cuesta Valdez" on the herbarium label. Triangulation from other herbarium label notes puts this location most likely at the west fork of Trident Canyon at an elevation of $370 \mathrm{~m}$. Finally, there is an unvouchered discovery in Lady's Canyon above Lady's Harbor (Site 6, fig. A-2) by P. Schuyler in 1985; documentation and field notes are missing (P. Schuyler, Catalina Island Conservancy, oral commun., 2005).

There are at least two, and perhaps as many as five, genetic individuals being cultivated at botanic gardens, but it is not clear which wild $B$. pinnata ssp. insularis plants several of them are. One large plant at SBBG was derived from a cutting made in the 1960s of the Campo Raton individual; others at SBBG are derived from this plant either as cuttings or fruits (D. Wilken, Santa Barbara Botanic Garden, oral commun., 2005). An B. pinnata ssp. insularis plant in cultivation at the University of California Santa Cruz Arboretum is likely not from the Campo Raton roadside plant, as it was apparently collected near there but much farther upslope in 1979. Cuttings from this plant were introduced into the horticultural trade as "Shnilemoon barberry" (S. McCabe, University of California Santa Cruz, oral commun., 2006) in the 1980s. Finally, two B. pinnata ssp. insularis clones are at the University of California Berkeley Botanical Garden. One collected by R. Gankin in 1963 is from an unknown location, and the second is from the Shnilemoon cultivar at the University of California Santa Cruz Arboretum (S. Novak, University of California Santa Cruz, oral commun., 2007). 


\section{Field Surveys}

We searched for 5 of the 7 historical B. pinnata ssp. insularis plants during the flowering seasons of 2005 and 2006 (table 7); we were able to relocate four of them. In 2005, we found one plant each at Campo Raton, in the Upper Cañada Christy area, and in the east fork of Trident Canyon. The Hazard's Canyon barberry site was relocated in April 2006, with transportation provided by the National Oceanic and Atmospheric Administration (NOAA) Channel Islands National Marine Sanctuary. The plant reported in Lady's Canyon was not found. Historical notes on this plant are missing, making it difficult to pinpoint a locality. Therefore, we searched the likely habitat around the estimated location. According to P. Schuyler (Catalina Island Conservancy, oral commun., 2006), who discovered this plant in 1985, native plants have recovered in the canyon bottom, perhaps out-competing the Berberis, or obscuring it from view. Alternatively, since this is a rather entrenched canyon bottom, major storm events could have washed the plant away. Plans for future searches need to take into account that this is a difficult canyon to descend into and traverse along the canyon bottom.

Species descriptions by Williams (1993) and Munz and Keck (1959) depict B. pinnata ssp. insularis as having "reclining or vine-like" stems. However, not all of the four barberry plants we found fit this description, and each is strikingly different from the others in size and branching structure. The Campo Raton plant was described as a large shrub in 1927 and 1932; it had been reported missing by botanists since the late 1990s (L. Laughrin, University of California Santa Cruz Island Reserve, oral commun., 2004). In 2005, we located two juvenile shoots growing about $2 \mathrm{~m}$ $(6.6 \mathrm{ft})$ south of the road, a few meters west of where the old plant had lived for at least most of a century. These shoots, consisting of young woody tissue, were approximately 30 $\mathrm{cm}$ (11.8 in) tall and were about $30 \mathrm{~cm}$ apart. An additional two shoots were found upslope about $7 \mathrm{~m}(23.0 \mathrm{ft})$ to the south-southwest; they were about $15 \mathrm{~cm}$ (5.9 in) apart and were roughly 30 and $75 \mathrm{~cm}$ (29.5 in) tall. All four shoots were vegetative with no sign of inflorescences. These could be offshoots from the old shrub, or they could be new individuals growing near where the old shrub lived. Genetic analyses would need to be done to determine how many individuals there are and whether these shoots are from the same plant being cultivated at the SBBG.

The B. pinnata ssp. insularis in Upper Christy had nine stems in 2005: one was flowering with three inflorescences. The longest were decumbent down the slope, with foliage generally only $20-40 \mathrm{~cm}$ (8-16 in) off the ground. Additional upslope stems of this plant were approximately $1 \mathrm{~m}(3.3 \mathrm{ft})$ tall, erect, and intermingled with and leaning on Heteromeles arbutifolia.

The plant in the east fork of Trident Canyon was a large shrub with 30-40 erect-to-leaning stems and approximately 72 branches with one or more inflorescences each. These stems ranged from less than 1 to $4 \mathrm{~m}(3.2$ to $13.1 \mathrm{ft})$ in height and were generally tightly clustered together. At least nine root sprouts were growing around the periphery of the main plant. This plant was the largest of those surveyed and had the most flowering stems.

The Hazard's plant was strikingly different from the others. It had 22 mostly erect stems that were more widely scattered, more variable in size, and covered a larger area than the stems of the other three plants. In April, 2006, six of the stems were flowering and fruiting, although only about two dozen small, reddish developing fruits were seen.

Table 7. Results of the surveys of Berberis pinnata ssp. insularis plants, the approximate area they occupy, and total number in each population on Santa Cruz Island, California, 2005-2006.

[ $\mathrm{m}^{2}$, square meter; km, kilometer; WNW, west north west]

\begin{tabular}{|c|c|c|c|c|c|}
\hline \multirow{2}{*}{$\begin{array}{c}\text { Site } \\
\#\end{array}$} & \multirow{2}{*}{ Date } & \multirow{2}{*}{ Site name } & \multirow{2}{*}{$\begin{array}{c}\text { Area } \\
\left(\mathrm{m}^{2}\right)\end{array}$} & \multicolumn{2}{|c|}{ Plant counts } \\
\hline & & & & 2005 & 2006 \\
\hline 1 & $04-05-05$ & Campo Raton & 7 & 1 & 1 \\
\hline 2 & 04-07-05 & Upper Christy (Centinella Grade) & 6 & 1 & 1 \\
\hline 3 & 04-20-06 & Hazard's Canyon & 25 & not surveyed & 1 \\
\hline 5 & 03-13-05 & Trident Canyon east fork ${ }^{1}$ & 18 & 1 & 1 \\
\hline 6 & Not visited & Upslope of Campo Raton & unknown & not surveyed & not surveyed \\
\hline 4 & Not visited & $2.3 \mathrm{~km} \mathrm{WNW} \mathrm{Diablo} \mathrm{Peak}$ & unknown & not surveyed & not surveyed ${ }^{1}$ \\
\hline 7 & 04-30-05 & Lady’s Canyon & unknown & surveyed, none found & not surveyed \\
\hline
\end{tabular}

\footnotetext{
${ }^{1}$ Note: This site was surveyed and one robust individual was found in 2008.
} 


\section{Plant Voucher Specimens and Seed Collections}

One herbarium voucher specimen was collected from the large plant at Trident Canyon in 2006 (fig.1, table 8). Plants at the other sites were too small to collect, but were photographed. The digital photographs are archived in the USGS and Channel Islands National Park computer image library.

We attempted to collect seed from the Upper Christy and Trident Canyon barberries. Both plants flowered vigorously in 2005 and less vigorously in 2006, but their fruits aborted before reaching maturity in both years. There was no clear, visible evidence of insect or fungal activity on the flowers, but fruit-boring insect exit holes were observed on aborted fruits at the Trident site in both years. The B. pinnata ssp. insularis plants at the SBBG have been observed to set fruit only occasionally over the past several decades (S. Junak, Santa Barbara Botanic Garden, oral commun., 2004). There is no obvious correlation between fruiting and weather patterns, and reasons for sporadic seed set have not been studied. Dieter Wilken has had limited success hand-pollinating island and mainland barberry plants at the SBBG. Hand pollination requires daily visits, difficult to achieve for the plants in their native habitats.

Instead of fruits, root sprouts were collected in 2006 from the Hazards and Trident plants for propagation at SBBG. Three root sprouts were taken in April from the Hazard's Canyon plant for cultivation at SBBG; one appears to have survived transplanting. Two small root sprouts were also collected from the Trident Canyon plant during March 2006 and were cultivated at SBBG, but these cuttings did not survive. This is a large, fairly easily accessible plant that

Table 8. Berberis pinnata ssp. insularis fruits, root cuttings and voucher specimens collected in 2006, Santa Cruz Island, California.

\begin{tabular}{lccc}
\hline \multicolumn{1}{c}{$\begin{array}{c}\text { Site } \\
\text { name }\end{array}$} & Fruits & $\begin{array}{c}\text { Root } \\
\text { cuttings }\end{array}$ & $\begin{array}{c}\text { Voucher } \\
\text { specimens }\end{array}$ \\
\cline { 2 - 4 } & \multicolumn{3}{c}{$\mathbf{2 0 0 6}$} \\
\hline Campo Raton & 0 & 0 & 0 \\
Hazard's Canyon & 0 & 3 & 0 \\
Trident Canyon east fork & 0 & 2 & 1 \\
Upper Christy (Centinella & 0 & 0 & 0 \\
$\quad$ Grade) & & & \\
\hline
\end{tabular}

would be a good candidate for tissue cultures from future cuttings or samples.

\section{Dudleya nesiotica (Moran) Moran Santa Cruz Island live-forever)}

\section{Collection History}

Dudleya nesiotica, a single-island endemic in the Crassulaceae family, is a succulent perennial with an unusual growth habit: it produces a long-lived underground cormlike stem with above-ground succulent stems and leaves produced in spring that dry in summer but persist after drying (Junak and others, 1995). It is known and verified from one general location on the west end of the island (Junak and others, 1995). The southernmost two of the six sites shown in figure A-3 represent known populations at or near Fraser Point and Forney's Cove (Sites 1 and 2, figs. 1, A-3).

The Fraser Point population (Site 1) has been studied by D. Wilken, who counted and measured plants in plots from 1994 to 2003 and studied pollination from 1994 to1996 (D. Wilken, 1996). Nancy Vivrette has sampled plant frequency and cover in the area along a permanent transect from 1979 to the present (N. Vivrette, Santa Barbara Botanic Garden, unpub. data, 2007). TNC biologist Rob Klinger and volunteers also monitored these populations in the early 1990s, but we do not have access to those data. Both the Wilken and Vivrette studies document a high degree of fluctuation in D. nesiotica patch size, apparently correlated with fluctuations in precipitation.

\section{Field Surveys}

D. nesiotica was surveyed and mapped on the marine terrace north of Fraser Point in 2005 by NPS Botanist Sarah Chaney and S. McCabe, U.C. Santa Cruz Arboretum Curator of Succulents, following an unverified report of a population slightly farther north near the shore (P. Aigner, University of California Riverside, oral commun, 1999). They found several patches of $D$. nesiotica about $750 \mathrm{~m}(0.5 \mathrm{mi})$ north of Forney's cove and east-northeast of the tip of Fraser Point on the same major marine terrace as the Fraser Point population (Site 3; table 9, figs. 1, A-3) This site appears to be that of a 1959 C. Smith collection (S. Junak and others 1995). McCabe, a Dudleya taxonomist, hypothesizes that $D$. nesiotica hybridizes with other island live-forevers, including $D$. greenei and D.Xcandelabrum. He documented and collected both pure D. nesiotica and Dudleya hybrids at the site. 
The west end of the island was surveyed again in May and June 2006 (table 9, fig. A-3). In May 2006, McCabe and USGS botanists mapped and collected live-forevers along the north shore of the West End Flats (figs. 1, A-3, Sites 4, 5, and 6). No D. nesiotica were found, but D. nesiotica x greenei hybrids were discovered within previously known stands of D. greenei in rock outcrops near the upper edge of the coastal bluffs (Sites 4 and 5) and in barren eroded areas on the inland border of the wide marine terrace adjacent to the north shore (Site 6). In addition, locations of a few similar hybrid plants were mapped on the marine terrace north of Fraser Point (Site 3).

\section{Plant Voucher Specimens and Seed Collections}

The remaining sites were visited in June 2006; S. McCabe made collections (table 10) for off-site cultivation at the U.C. Santa Cruz Arboretum (S. McCabe, U.C. Santa Cruz, written commun. 2006). McCabe is currently researching the systematics of California Dudleya species. He made live plant and voucher collections to clarify taxonomy of the Santa Cruz Island species. Plants were propagated from the live collections, and they remain in cultivation at the University of California Santa Cruz Arboretum for further study.

Table 9. Dudleya nesiotica and Dudleya nesiotica x D. greenei survey results from Santa Cruz Island, California, 2005-2006: approximate area occupied and total plants in populations.

$\underline{\left[\mathrm{m}^{2}, \text { square meter; } \mathrm{m}, \text { meter; NW, northwest }\right]}$

\begin{tabular}{|c|c|c|c|c|c|}
\hline \multirow{2}{*}{$\begin{array}{l}\text { Site } \\
\text { No. }\end{array}$} & \multirow{2}{*}{ Taxon } & \multirow{2}{*}{ Date } & \multirow{2}{*}{ Site name } & \multirow{2}{*}{$\begin{array}{c}\text { Area } \\
\left(\mathrm{m}^{2}\right)\end{array}$} & \multirow{2}{*}{$\begin{array}{c}\text { Plant counts } \\
2006\end{array}$} \\
\hline & & & & & \\
\hline 1 & D. nesiotica & $\begin{array}{l}05 / 29 / 06 \\
06 / 13 / 06\end{array}$ & Fraser Point & 48,000 & $30,000-50,000$ \\
\hline 2 & D. nesiotica & $\begin{array}{l}05 / 29 / 06 \\
06 / 13 / 06\end{array}$ & Forney's Cove & 30,000 & $10,000-20,000$ \\
\hline 3 & D. nesiotica & $\begin{array}{l}06 / 20 / 05 \\
05 / 29 / 06 \\
06 / 13 / 06\end{array}$ & $\begin{array}{l}\text { Marine Terrace } \\
\text { North of Fraser } \\
\text { Point }\end{array}$ & 45,000 & $1000-5000$ \\
\hline 4 & Hybrids & 05/28/06 & $\begin{array}{l}\text { Northwest } \\
\text { terraces, } \\
\text { Coastal ( } 670 \mathrm{~m} \\
\text { east of NW tip) }\end{array}$ & 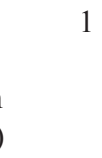 & 1 \\
\hline 5 & Hybrids & $05 / 28 / 06$ & $\begin{array}{l}\text { Northwest } \\
\text { terraces, } \\
\text { Coastal }(500- \\
550 \text { m east of } \\
\text { NW tip) }\end{array}$ & 150 & 3 \\
\hline 6 & Hybrids & 05/28/06 & $\begin{array}{l}\text { Northwest } \\
\quad \text { terraces, Inland }\end{array}$ & 3,900 & $5-20$ \\
\hline
\end{tabular}

\section{Galium buxifolium Greene (sea-cliff bedstraw)}

\section{Collection History}

Galium buxifolium is a fragile subshrub in the Rubiaceae family. It is closely related to Galium catalinense and, in the past, has been called Galium catalinense var. buxifolia. Many Galium species have flowers that are imperfect to some degree (Dempster, 1993), and G. buxifolium has been described as "usually dioecious" (Junak and others, 1995) as well as "imperfectly dioecious" or "variably polygamous" (Dempster, 1973). G. buxifolium is typically found on coastal bluffs protected from trampling by livestock. Hochberg and others (1980) reported that it was more widespread on the marine terraces along the coastal bluffs before the sheep ranching era.

An island endemic, G. buxifolium is currently known from Santa Cruz and San Miguel Islands. It was collected from Santa Rosa Island by R. Hoffmann in 1930, but recent searches there have not found any plants. On San Miguel Island, five sites were documented along the north shore between Harris Point and Cardwell Point between 1961 and 1998. G. buxifolium was first collected on Santa Cruz Island in 1886 by E.L. Greene. At least 12 herbarium specimens collected by Greene were vaguely labeled "Santa Cruz Island, July-August 1886," so a more accurate location probably will never be known.

Table 10. Dudleya nesiotica and D. nesiotica x D. greeneifruits, live cuttings, and voucher specimens collected by Stephen McCabe, University of California Santa Cruz during 2004-2006, Santa Cruz Island, California.

[Live plants and voucher specimens collected by Stephen McCabe, University of California Santa Cruz]

\begin{tabular}{|c|c|c|c|c|}
\hline Taxon & Date & Site name & $\begin{array}{l}\text { Live } \\
\text { plants }\end{array}$ & $\begin{array}{c}\text { Voucher } \\
\text { specimens }\end{array}$ \\
\hline D. nesiotica & $06-13-06$ & Fraser Point & 6 & 2 \\
\hline D. nesiotica & $06-13-06$ & Forney's Cove & 0 & 0 \\
\hline $\begin{array}{l}\text { D. nesiotica } \mathrm{x} \\
\text { D. greenei }\end{array}$ & 06-13-06 & Forney's Cove & 0 & 0 \\
\hline D. nesiotica & 06-13-06 & $\begin{array}{l}\text { Marine terrace } \\
\text { North of Fraser } \\
\text { Point }\end{array}$ & 0 & 0 \\
\hline $\begin{array}{l}\text { D. nesiotica x } \\
\text { D. greenei }\end{array}$ & $06-13-06$ & $\begin{array}{l}\text { Marine terrace } \\
\text { North of Fraser } \\
\text { Point }\end{array}$ & 0 & 1 \\
\hline $\begin{array}{l}\text { D. greenei or } \\
\text { D. nesiotica } \\
\text { x D. greenei }\end{array}$ & $06-13-06$ & $\begin{array}{l}\text { Marine terrace } \\
\text { North of Fraser } \\
\text { Point }\end{array}$ & 2 & 4 \\
\hline $\begin{array}{l}\text { D. nesiotica } \mathrm{x} \\
\text { D. greenei }\end{array}$ & $05-28-06$ & Northwest terraces & 1 & 1 \\
\hline $\begin{array}{l}\text { D. nesiotica } \mathrm{x} \\
\text { D. greenei }\end{array}$ & $05-28-06$ & Northwest terraces & 1 & 1 \\
\hline $\begin{array}{l}\text { D. greenei or } \\
\text { D. nesiotica } \\
\text { x D. greenei }\end{array}$ & $05-28-06$ & Northwest terraces & 0 & 1 \\
\hline
\end{tabular}


Thirteen historical G. buxifolium populations were documented on Santa Cruz Island from 1930 to 1979 (Sites 1-13, table 11, fig. A-4). Eleven of these thirteen are on sea cliffs along the north shore of the island between Eagle Canyon to the east and Hazard's Anchorage to the west (fig. 1). Two additional sites are much more inland than the typical coastal distribution. One population (Site 8) is in the Buena Vista region of the western Central Valley; a voucher specimen was collected there by Michael. Benedict in 1968 (Junak and others, 1995). The other (Site 13) was observed in April 1984 by P. Schuyler in an area described as the "uplands between 2nd \& 3rd drainages E of Forney's Cove" (S. Junak, Santa Barbara Botanic Garden, oral commun. 2005); there are no herbarium specimens from this site.

\section{Field Surveys}

Table 11 gives G. buxifolium survey results. Thirteen populations (Sites 1-13) were known from records of collections; we searched for ten of them 2004 through 2006, and found plants still growing at seven. All seven were on north-facing vertical sea cliff faces, sometimes extending onto the slopes immediately above or the talus slopes below the vertical faces. The Pelican Bay population (Site 4, figs. 1, A-4) is unusual because most of the G. buxifolium plants grow on the slopes and flats on the terrace above the bluff face. We did not find plants at 3 of the 13 sites. The inland habitat near Buena Vista (Site 8) was surveyed several times in 2004, and no plants were found. Although this site may have been documented as recently as 1979 (Hochberg, 1980), only vague location information exists, and it is possible that the information given is in error. The site described as "west of the Lookout at Prisoner's" (Site 11) also lacks detailed locality information. We could not find G. buxifolium near our best estimate of the coordinates, and the area had extensive pig rooting and loose, eroding soil. Finally, no plants were found at the location about $1 \mathrm{~km}(0.6 \mathrm{mi})$ west of Cueva Valdez beach (Site 12). Three other remote locations were not surveyed; those were along the north shore of the island at Hazard's and Fry's Harbors (Sites 1 and 10) and on the west end east of Forney's Cove (Site 13).

In addition to the historical relocations, we discovered 14 new G. buxifolium sites. In late May of 2004, we surveyed suitable habitat in the region of Cañada del Agua, east of all the known populations. We found five distinct patches scattered along the bluffs above the long beach at Cañada del Agua, on either side of the mouth of Cañada del Agua, and above the small pocket beaches just east and west of the long beach. Four of these patches fall within $200 \mathrm{~m}(656.1 \mathrm{ft})$ of each other and are clustered between the canyon mouth region and the two small beaches west of the large beach at Cañada del Agua mouth; these four patches are treated as one site for this report. The fifth patch is about $0.8 \mathrm{~km}(0.5 \mathrm{mi})$ east of the mouth of Cañada del Agua. Bluff slopes between these mapped sites were not surveyed. These two new occurrences are shown as sites 14 and 15 in table 11 and figure A-4.

Another new site was found in March 2005, north of and downslope from the Pelican Trail, in the Marine Gardens area between Prisoner's and Pelican Bay (Site 16 in table 11 and fig. A-4). Vegetation on this rocky coastal slope was mixed coastal bluff scrub, pine forest, and chaparral. Only one G. buxifolium plant was seen; this area warrants further surveys.

In June 2005, three patches of G. buxifolium were discovered along the West End Flats, immediately east of Del Mar Cove, listed as Sites 17-19 in table 11 and figure A-4. These three sites have plants on or near the flats above the coastal bluffs. Surveys here did not include the adjacent coastal slopes and bluffs below the populations, where there are probably more G. buxifolium plants. More surveys are warranted in this region.

In April through May 2006, eight new G. buxifolium sites were discovered. Seven of these were scattered along the western part of the north shore of the island, from the cove just east of Hazard's Anchorage to the West End (Sites 20-26). The area east of Hazard's Canyon and the coastal bluffs and marine terrace edges west of Del Mar Cove were also surveyed. The eighth 2006 location (Site 27) was just west of Marine Gardens, between Prisoner's Harbor and Pelican Bay. The Marine Gardens site is unusual because it is among rock outcroppings on a slope strewn with variously sized boulders rather than consolidated bluff face.

One of the greatest challenges in quantifying $G$. buxifolium populations is difficult access. The sea-cliff sites are generally accessible from above or below, but usually not both, and often the plants are difficult to see because vegetation and bluff terrain obscure the plants. Ideally, sites would be surveyed from above and below; this would take significantly more time and funding than used in this study. Therefore, the counts and the area occupied reported in table 11 are minimum counts or estimates of visible plants. Individuals were counted using binoculars, and estimates were made occasionally where plants were clustered and appeared to be more than one individual.

In 2004, sites were documented mostly from below from the shore (for example, Lady's and Baby's Canyons, Cueva Valdez, Eagle Canyon and regions near and including Cañada del Agua). Surveys were made from above the bluffs at Pelican Bay and the three sites along the West End Flats/east of Del Mar Cove. Of the eight sites found during 2006, seven of them were found from above. Only the Marine Gardens West site was discovered from below (by kayak), and it has a very incomplete site description because it was observed from a distance. The bluffs east of Prisoner's and Tinker's Cove could be surveyed from both above and below. Four sites were chosen for long-term demography monitoring (Sites 4, 6, 7, and 9 , table 11). 
Table 11. Results of the surveys of Galium buxifolium populations, the approximate area they occupy, and the total number in each population on Santa Cruz Island, California, 2004-2006.

[m², square meter; km, kilometer; W, west; E, east; NW, northwest; +, may be more than the number given; $\sim$, about]

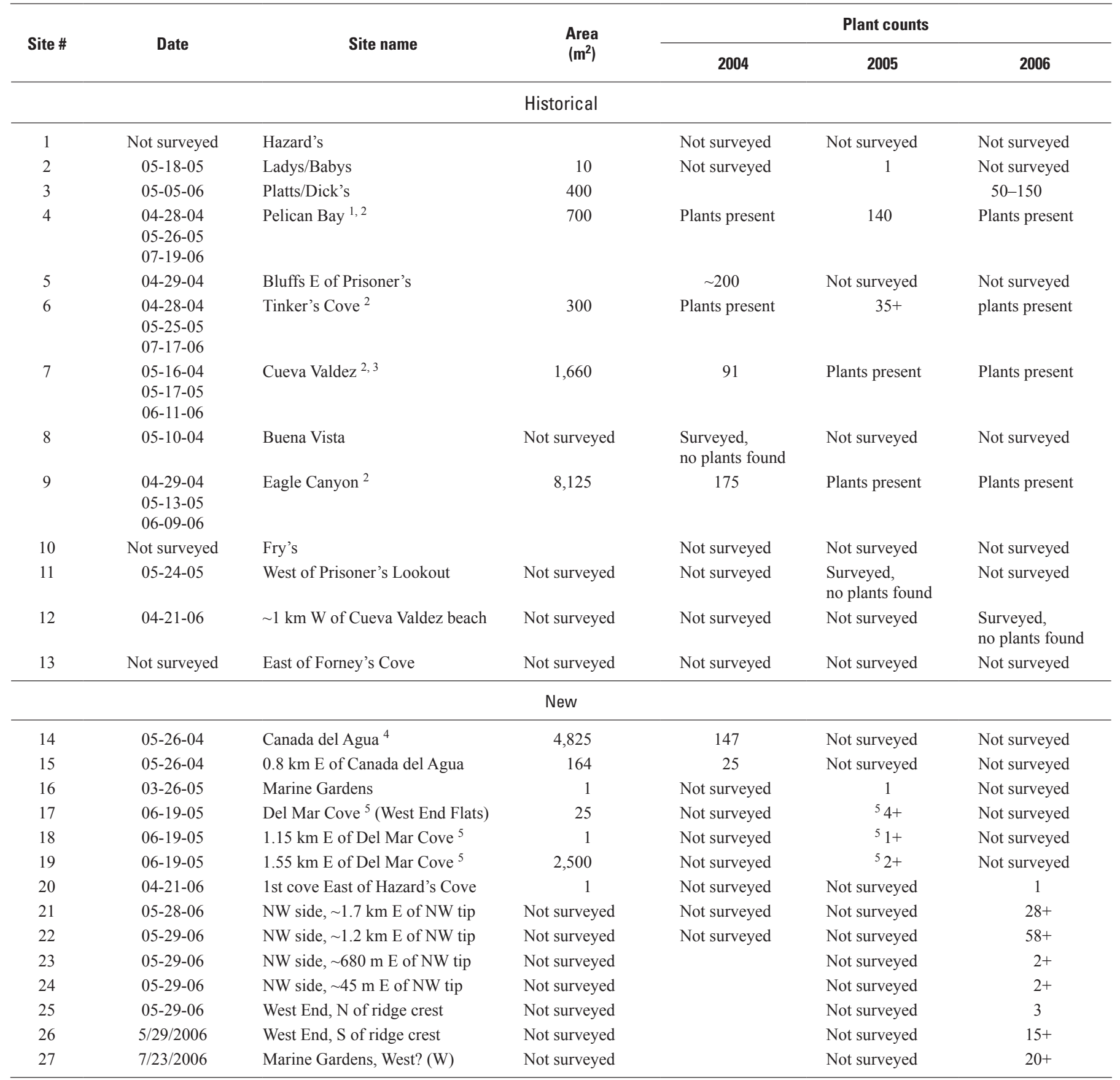

${ }^{1}$ This site consists of two historical sites located within $130 \mathrm{~m}$ of each other: (1) Pelican, above and east of landing, (2) Pelican, west of landing.

${ }^{2}$ Demography study site.

${ }^{3}$ This site consists of two historical sites and one new site located within 100 to $220 \mathrm{~m}$ of each other: (1) Ledge W of talus slope, (2) Talus slope, W of Cueva Valdez beach, and (3) Areas immediately surrounding mouth of larger canyon at Cueva Valdez.

${ }^{4}$ This site consists of four new subsites located east of Eagle Canyon: (1) Bluffs above small beaches immediately W of beach at Cañada del Agua, (2) Three patches on bluffs above beach W of Cañada del Agua Canyon mouth, (3) Patch inside canyon walls of mouth of Cañada del Agua, and (4) Patch 50 m E of mouth of Canada del Agua.

${ }^{5}$ National Park Service Botanist and S. McCabe discovered these sites, independent from U.S. Geological Survey work. Adjacent bluffs were not surveyed; likely several to many more plants exist on vertical bluffs below. 


\section{Plant Voucher Specimens and Seed Collections}

One or two voucher specimens were collected at each of Pelican Bay, Tinker's Cove, Cueva Valdez, and Eagle Canyon in April and May 2004 and May 2005 (table 12). Only three specimens were collected from new sites in 2006, because populations were small and we did not want to reduce seed available for population expansion up the bluff or onto the flat terraces above the more densely occupied coastal bluffs. Seeds were collected June-August 2005 and August-September 2006, from Eagle Canyon, Pelican Bay, Tinker's Cove, and Cueva Valdez. These sites were re-visited July-September to track fruit development and identify ideal fruit maturation stage in order to determine the best time to collect seeds for propagation. Table 12 shows collections made by site and year.

Fruit and seed production varies greatly within each population, and seed production appears related to floral biology. G. buxifolium plants are reported to be bisexual, or unisexual with sterile stamens or pistils (Dempster, 1993). Dempster (1973) observed that plants within the genus span a range of floral types, with the group including G. buxifolium tending toward dioecy without being fully dioecious. However, Dempster's studies were based on herbarium specimens, which may be biased as to sex ratio. This group ranges from plants with mostly pistillate or mostly staminate flowers, to plants with mostly perfect flowers on a single individual. Individual plants that are mainly pistillate or staminate may also have a low proportion of perfect flowers. Likewise, plants with mainly perfect flowers may have a low proportion of either unisexual type. Plants at demography monitoring sites are a mixture of floral types, including plants that are either predominantly staminate or mainly pistillate. If a plant has perfect flowers, they are either alone or combined with pistillate flowers only. However, plants grown in the nursery from seeds from the same populations thus far have produced female and bisexual (hermaphroditic) flowers in about a 1 to 1 ratio (D. Wilken, Santa Barbara Botanic Garden, unpub. data, 2006). Most of these seeds came from a large plant at the Cueva Valdez site; more work with seeds from other sites is needed. Santa Cruz Island field-grown plants with mostly unisexual flowers of either type tend to produce smaller and fewer fruits than plants with bisexual flowers. If a population is skewed toward either type of unisexual floral biology, it may produce fewer fruits and have lower recruitment rates than populations with a higher proportion of predominantly bisexual individuals. Lowered fecundity could reduce recovery probabilities for such isolated populations.
We collected seed in 2005 and 2006 to bank at the SBBG and to study floral biology and seed production in collaboration with Dieter Wilken (table 12). Table 12 shows the approximate numbers of seeds collected. G. buxifolium produces 1 or 2 seeds per fruit, and often the seeds are unequal in size or aborted and difficult to count within one fruit.

Therefore, seed counts are given as a range in the table. About half of the seeds were deposited at the SBBG seed bank. The rest are being used for viability and floral biology research and outplanting experiments on Santa Cruz Island.

\section{Helianthemum greenei B.L. Rob (island rush-rose)}

\section{Collection History}

Helianthemum greenei is a small, brittle, short-lived sub-shrub in the Cistaceae family and is endemic to three of the Channel Islands. It was first collected on Santa Cruz Island in 1888 by T.S. Brandegee, but the location was not specified. E.L. Blakley collected H. greenei on Santa Catalina Island in 1962. H. greenei was known from a single collection in the 1930s on Santa Rosa Island and was re-discovered there in a fenced exclosure by NPS botanists in 1999. At least 43 sites were documented on Santa Cruz Island by herbarium voucher collections made between 1930 and 1997 (fig. A-5). In 2001, NPS botanists found this species on the east end of Santa Cruz Island two years after sheep removal. It had not been reported previously from the east end.

Table 12. Galium buxifolium seeds and voucher specimens collected during 2004-2006, Santa Cruz Island, California.

\begin{tabular}{lccccccc}
\hline \multirow{2}{*}{$\begin{array}{c}\text { Site } \\
\text { name }\end{array}$} & \multicolumn{3}{c}{ Total seeds } & & \multicolumn{3}{c}{ Voucher specimens } \\
\cline { 2 - 4 } \cline { 5 - 7 } & $\mathbf{2 0 0 4}$ & $\mathbf{2 0 0 5}$ & $\mathbf{2 0 0 6}$ & & $\mathbf{2 0 0 4}$ & $\mathbf{2 0 0 5}$ & $\mathbf{2 0 0 6}$ \\
\hline Pelican Bay & 0 & $898-1016$ & $329-344$ & & 1 & 0 & 0 \\
Tinker's Cove & 0 & $32-52$ & 25 & 1 & 0 & 0 \\
Cueva Valdez & 0 & $2028-2768$ & 66 & 1 & 0 & 1 \\
Eagle Canyon & 0 & $1230-1752$ & 42 & & 1 & 1 & 0 \\
Platts/Dick's & 0 & 0 & 0 & 0 & 0 & 1 \\
$\begin{array}{l}\text { West End, S of } \\
\text { ridge crest }\end{array}$ & 0 & 0 & 0 & 0 & 0 & 1 \\
\hline
\end{tabular}




\section{Field Surveys}

Because $H$. greenei is widely scattered in small, shortlived populations in many Santa Cruz Island locations, we did not search for specific, historically documented sites. Instead, we documented plants found during the course of field work conducted 2001 through 2006 . We found 36 groups of plants clustered at 22 sites 2001 through 2006; table 13 lists these locations. Historical locations are so numerous and scattered across the landscape that place name designations are difficult to assign and less meaningful than those assigned to the other taxa in this document. Therefore, these historical sites are not listed in a table, but are displayed in figure A-5.

Table 13. New populations documented for Helianthemum greenei, the approximate area they occupy, and the total number in each population on Santa Cruz Island, California, 2001-2006.

[S, south; E, east; N, north; W, west; km, kilometer; m, meter; , about]

\begin{tabular}{|c|c|c|c|}
\hline $\begin{array}{c}\text { Site } \\
\#\end{array}$ & Date & Site name & $\begin{array}{l}\text { Plant } \\
\text { counts }\end{array}$ \\
\hline 1 & $03-29-01$ & Yellowbanks (3 groups) & 32 \\
\hline 2 & 04-19-02 & SE fork Scorpion (2 groups) & 18 \\
\hline 3 & $\begin{array}{l}03-27-01 \\
05-05-02\end{array}$ & NW fork Scorpion (2 groups) & 3 \\
\hline 4 & 06-01-02 & $1.8 \mathrm{~km} \mathrm{~S}$ of Painted Cave & $30-40$ \\
\hline 5 & $06-26-02$ & Lower Canada del Puerto & 1 \\
\hline 6 & $06-27-02$ & Upper Diablo Canyon & 1 \\
\hline 7 & 04-06-03 & Upper W fork Laguna (2 groups) & $6-10$ \\
\hline 8 & $04-20-03$ & Middle E fork Laguna (2 groups) & 2 \\
\hline 9 & $05-15-03$ & Eastern Johnson region (3 groups) & 40 \\
\hline 10 & $06-07-03$ & W of Prisoner's Lookout & 1 \\
\hline 11 & $05-12-04$ & Cebada Ridge (2 groups) & 101 \\
\hline 12 & 05-18-05 & Lady's Harbor & 7 \\
\hline 13 & $07-06-05$ & Cueva Valdez & $300-500$ \\
\hline 14 & $09-25-05$ & Albert's Ridge & 9 \\
\hline 15 & 04-20-06 & $\begin{array}{l}\text { Ridge E of Hazard's Canyon } \\
\text { ( } 5 \text { groups })\end{array}$ & $200-400$ \\
\hline 16 & $04-20-06$ & Hazard's Canyon (2 groups) & $10-20$ \\
\hline 17 & 06-01-06 & $\sim 260 \mathrm{~m} \mathrm{~W}$ of Orizaba Cove & $20-25$ \\
\hline 18 & 06-01-06 & $\sim 370$ and $480 \mathrm{~m} \mathrm{~S}$ of Orizaba Cove & 11 \\
\hline 19 & 06-01-06 & $\sim 680 \mathrm{~m} \mathrm{~S}$ of Orizaba Cove & 2 \\
\hline 20 & 06-01-06 & $\sim 350 \mathrm{~m}$ SE of Orizaba Cove & 67 \\
\hline 21 & 06-11-06 & Ridge E of Cueva Valdez Harbor & 2 \\
\hline 22 & $12-04-06$ & Christy Pines W & 1 \\
\hline
\end{tabular}

\section{Plant Voucher Specimens and Seed Collections}

Voucher specimens were collected at only 3 sites (table 14), as most sites had too few individuals to justify taking any plants or branches. Seeds were not collected.

\section{Malacothamnus fasciculatus (Torr. \& A. Gray) Greene var. nesioticus (B.L. Rob.) Kearney (Santa Cruz Island bush mallow)}

\section{Collection History}

Malacothamnus fasciculatus var. nesioticus, a long-lived, clonal shrub in the Malvaceae family, is restricted to Santa Cruz Island. It was first collected by E.L. Greene in 1886 in an unspecified location. There are four known populations of M. fasciculatus var. nesioticus: at Christy Ranch (Site 1), in a ravine across the Central Valley northward from the U.C. Field Station (Site 2), on Horqueta-Alamos Ridge (Site 3), and on Cebada Ridge (Site 4) (table 15, fig. A-6). In 1927, H. L. Mason collected a specimen at what was probably the Christy Ranch population, although he recorded "West Ranch" as the place name. The Christy Ranch was definitely the location where it was collected by Ralph Hoffmann in 1930. The population across the creek north of the U.C. Field Station on a steep, south-facing canyon slope was discovered by A. Wenner and S. Gliessman in 1993 (S. Gliessman, University of California Santa Barbara, oral commun., 2004; Wilken, 1996), and the population on the ridge between Horqueta and Alamos drainages was discovered in 1997. In May 1997, D. Wilken collected herbarium voucher specimens at the U.C. Field Station and the Horcherta-Alamos Ridge sites. In 2003, Wilken also collected voucher specimens at the Cebada Ridge population that appeared in 2000, following the Pozo Pasture controlled burn on the ridge between Cañada Cebada and Cañada de los Sauces. Additionally, stem cuttings were collected between the early 1990s and 2000, from the Christy, U.C. Field Station, and Horqueta-Alamos plants for off-site living collections at the SBBG (A. Wyatt, Santa Barbara Botanic Garden, oral commun., 2004).

Table 14. Helianthemum greenei voucher specimens collected 2004-2006, Santa Cruz Island, California.

$[\mathrm{m}$, meter; -, not surveyed; $\sim$, about $]$

\begin{tabular}{lccc}
\hline \multirow{2}{*}{ Site name } & \multicolumn{4}{c}{ Voucher specimens } \\
\cline { 2 - 4 } & $\mathbf{2 0 0 4}$ & $\mathbf{2 0 0 5}$ & $\mathbf{2 0 0 6}$ \\
\hline Lady's Harbor & 1 & 1 & - \\
$\begin{array}{l}\text { Cueva Valdez } \\
\sim 370 \text { and } 480 \text { m south of Orizaba } \\
\text { Cove }\end{array}$ & - & 1 & - \\
\hline
\end{tabular}




\section{Field Surveys}

All four known populations of M. fasciculatus var. nesioticus (table 15, fig. A-6) are still extant and were surveyed 2004-2006. The Christy Ranch site was visited in 2004 and 2006. Stems are widely scattered there, making it difficult to know how many genetic individuals are present at the site. Wilken visited this site almost annually between 1995 and 1999 and observed that there was no seed set during those years. The site north of the U.C. Field Station was surveyed in 2004. Stems at this site are dispersed similarly to those of the Christy site, and genetic individuals cannot be distinguished in the field. We unsuccessfully tried to find the Horqueta-Alamos Ridge site in 2004 and 2005, searching three different times. Location coordinates reported by earlier botanists apparently contained a transposition error: this population is actually $2 \mathrm{~km}(1.2 \mathrm{mi}) \mathrm{NE}$ of Corral Point, not $3.1 \mathrm{~km}(1.9 \mathrm{mi}) \mathrm{NNE}$ of Corral Point as previously recorded. We finally relocated the site in 2006, with assistance from D. Wilken. There were three clusters of stems, which we interpret as three multi-stemmed plants; only one of these clusters was reported in 1997.

The Cebada Ridge site was visited in 2004 and 2006. A population of three separate plants with hundreds of clonal stems each were known from surveys made by D. Wilken in 1999 and 2000 (D. Wilken, Santa Barbara Botanic Garden, written commun., 2004), and they were still apparent in 2004. In addition to these older plants, we mapped four more outlying plants located about 20, 50, 90, and $265 \mathrm{~m}$ (66, 164,295 and $870 \mathrm{ft}$ ) away. The farthest outlying plant was morphologically different from all others seen during 2004 surveys, with white rather than rose-pink petals, and it was growing in grassland with Baccharis pilularis and Artemisia californica rather than in the open areas between chaparral shrubs (Quercus pacifica, Rhus integrifolia), as is typical of

Table 15. Results of the surveys of Malacothamnus. fasciculatus var. nesioticus populations, the approximate area they occupy, and the total number in each population on Santa Cruz Island, California, 2004-2006.

[est \#, estimated number of; $\mathrm{m}^{2}$, square meter]

\begin{tabular}{|c|c|c|c|c|c|}
\hline \multirow{2}{*}{$\begin{array}{l}\text { Site } \\
\text { no. }\end{array}$} & \multirow{2}{*}{ Date } & \multirow{2}{*}{$\begin{array}{c}\text { Site } \\
\text { name }\end{array}$} & \multirow{2}{*}{$\begin{array}{c}\text { Area } \\
\left(\mathrm{m}^{2}\right)\end{array}$} & \multicolumn{2}{|c|}{$\begin{array}{l}\text { Stem counts } \\
\text { (est \# plants) }\end{array}$} \\
\hline & & & & 2004 & 2006 \\
\hline 1 & $\begin{array}{l}05-12-04 \\
07-11-06\end{array}$ & Christy Ranch & 300 & ${ }^{1} 20-40$ & $64(3)$ \\
\hline 2 & $05-15-04$ & $\begin{array}{l}\text { North of Field } \\
\text { Station }\end{array}$ & 50 & ${ }^{1} 18-20$ & $\begin{array}{l}\text { Not } \\
\text { surveyed }\end{array}$ \\
\hline 3 & 06-10-06 & $\begin{array}{l}\text { Horqueta-Alamos } \\
\text { Ridge }\end{array}$ & 1,100 & $\begin{array}{l}\text { Not } \\
\text { surveyed }\end{array}$ & $166(3)$ \\
\hline 4 & $\begin{array}{l}05-12-04 \\
07-11-06\end{array}$ & Cebada Ridge & 1,500 & $831(7)$ & $1137(10)$ \\
\hline
\end{tabular}

\footnotetext{
${ }^{1}$ Stems at these two sites were too widely scattered to know how many plants they likely represent.
}

the other plants in the Cebada area. These plants were all still present in 2006, along with yet three more outlying clusters of stems.

\section{Restoration Outplanting Projects}

Figure A-6 shows the locations of the native populations along with four additional sites used for $M$. fasciculatus var. nesioticus recovery outplanting experiments. We show the outplanted sites here to inform future surveys; these plantings are not at the sites of native populations. In 1995, several clones from the Christy and the U.C. Field Station living collections and grown at SBBG were planted in five fenced pig exclosures (Wilken 1996). Only one of these plants survived, at the Valley Anchorage exclosure. In 2005, we began a second outplanting experiment at four exclosures using cuttings from the same SBBG nursery-grown stock. Finally, a M. fasciculatus var. nesioticus plant is located at the southeast corner of the U.C. Field Station main building, apparently planted for landscaping by an unknown party between 1996 and 1998 (L. Laughrin, University of California Santa Cruz Island Reserve, oral commun., 2004).

\section{Plant Voucher Specimens and Seed Collections}

We collected voucher specimens at Christy and Cebada during 2004 surveys (table 16). No fruit or seed was collected from wild populations during this study, as fruit production was very low and sporadic during 2004-2006 across all four sites. D. Wilken (1996) reported that in 1994, he observed low fruit production in Christy plants and "relatively high" fruit production at the U.C. Field Station stand. He noted that the number of seeds per fruit was lower at Christy than at the U.C. Field Station population, and that seed production is increased when plants are out-crossed by hand pollination in the nursery. Entomologist Robin Thorpe (University of California Davis, oral commun., 2006) reports that he seldom sees pollinators of the Malvaceae in his inventories of Santa Cruz Island insects. Therefore, pollinator limitation may be a factor in poor seed set at one or more sites. We attempted a small hand-pollination field experiment, but found that more field time was needed to conduct the research than we had available with this funding.

Table 16. Malacothamnus fasciculatus var. nesioticus seeds and voucher specimens collected during 2004-2006, Santa Cruz Island, California.

\begin{tabular}{lccc}
\hline \multirow{1}{*}{ Site name } & \multicolumn{3}{c}{ Voucher specimens } \\
\cline { 2 - 4 } & $\mathbf{2 0 0 4}$ & $\mathbf{2 0 0 5}$ & $\mathbf{2 0 0 6}$ \\
\hline Christy Ranch & 2 & 0 & 0 \\
Cebada Ridge & 3 & 0 & 0 \\
\hline
\end{tabular}




\section{Malacothrix indecora Greene (Santa Cruz Island malacothrix)}

\section{Collection History}

Malacothrix indecora is an annual herb in the Asteraceae family and is endemic to three of the Channel Islands. The type specimen was collected from Santa Cruz Island in 1886 by E.L. Greene in an unspecified location. Table 17 lists the four sites documented on Santa Cruz Island, and their locations are shown in figure A-7. The population at Twin Harbors has not been visited since 1939, when plants were collected by M. W. Williams (Hochberg and others, 1980). The only site verified on Santa Cruz Island since this time is at Black Point, and voucher specimens were last collected there in 1980 .

M. indecora was collected at two locations on San Miguel Island by Hoffmann in 1932, and specimens were collected from these sites by S. Junak in 1995. In 1998, K. Chess surveyed these two San Miguel Island populations and discovered two more. This taxon was discovered on Santa Rosa Island by Wilken, Painter, and Chess in 1996. Surveys later that year documented a population of several patches on the marine terraces between the mouths of Lobos and Cow Canyons.

Table 17. Results of the surveys of Malacothrix indecora populations, the approximate area they occupy, and the total number in each population on Santa Cruz Island, California, 2003-2006.

\begin{tabular}{|c|c|c|c|c|c|c|}
\hline \multirow{2}{*}{$\begin{array}{l}\text { Site } \\
\text { No. }\end{array}$} & \multirow{2}{*}{ Date } & \multirow{2}{*}{$\begin{array}{c}\text { Site } \\
\text { name }\end{array}$} & \multirow{2}{*}{$\begin{array}{l}\text { Area } \\
\left(\mathrm{m}^{2}\right)\end{array}$} & \multicolumn{3}{|c|}{ Plant counts } \\
\hline & & & & 2003 & 2004 & 2006 \\
\hline 1 & $\begin{array}{l}\text { not } \\
\text { surveyed }\end{array}$ & $\begin{array}{l}\text { Twin } \\
\text { Harbors }\end{array}$ & 01 & not surveyed & not surveyed & not surveyed \\
\hline 2 & $\begin{array}{l}2003 \\
2004\end{array}$ & $\begin{array}{l}\text { Black } \\
\text { Point }\end{array}$ & $\begin{array}{l}0 \\
0\end{array}$ & $\begin{array}{l}\text { surveyed, } \\
\text { not found }\end{array}$ & $\begin{array}{l}\text { surveyed, } \\
\text { not found }\end{array}$ & not surveyed \\
\hline 3 & $\begin{array}{l}05-05-06 \\
06-01-06\end{array}$ & $\begin{array}{c}\text { E of Platts } \\
\text { Harbor }\end{array}$ & 91 & not surveyed & not surveyed & 125 \\
\hline 4 & 05-30-06 & $\begin{array}{l}\text { Potato } \\
\text { Harbor }{ }^{1}\end{array}$ & 91 & not surveyed & not surveyed & 18 \\
\hline
\end{tabular}

\footnotetext{
${ }^{1}$ One of three patches of Malacothrix species located during this survey. Other patches appear to be M. squalida (23 plants) and hybrids of M. indecora and M. squalida ( 9 plants).
}

\section{Field Surveys}

We searched for the Santa Cruz Island Black Point population in early June 2003 and 2004, but found no plants either time. This population occurred on a narrow peninsula used by seabirds most of the year. M. indecora has been censused annually on Santa Rosa Island 1996 through 2007 (Levine and others, 2008). In some years it has been nearly absent from those sites; therefore, it may be present only sporadically at Black Point. Annual searches should be made for several years before determining whether the species is extirpated from the site. In 2006, we discovered two new $M$. indecora sites (fig. A-7). One was found in early May at the east end of Platts Harbor (Site 3) during surveys for Arabis hoffmannii and Galium buxifolium. Another new site was discovered in late May, while surveying for M. squalida at Potato Harbor (Site 4). See the following M. squalida section for more discussion of findings at this site. Table 17 shows survey results, including the new discoveries.

\section{Plant Voucher Specimens and Seed Collections}

A voucher specimen was collected from each of the new sites upon discovery. No seeds were collected. Table 18 lists vouchers collected by site.

Table 18. Malacothrix indecora seeds and voucher specimens collected during 2006, Santa Cruz Island, California.

\begin{tabular}{lcc}
\hline \multicolumn{1}{c}{ Site name } & Total seeds collected & Voucher pecimens \\
\hline East of Platts Harbor & 19 & 1 \\
Potato Harbor & 0 & 1 \\
\hline
\end{tabular}

\section{Malacothrix squalida Greene (island malacothrix)}

\section{Collection History}

Malacothrix squalida is another annual herb in the Asteraceae family and is endemic to two of the Channel Islands. It was collected from Middle Anacapa Island in 1963 by M.A. Piehl. The type specimen was collected from Santa Cruz Island in 1886 by E.L. Greene from the Prisoner's Harbor region. A second Santa Cruz Island site was documented by voucher at Potato Harbor in 1968 by R.N. Philbrick. 


\section{Field Surveys}

The Prisoner's Harbor M. squalida locality is so poorly described that we could not relocate it. We surveyed for $M$. squalida at Potato Harbor in 2006 (table 19). The survey team included Steve Junak and Ralph Philbrick; Philbrick had been the last person to survey this site in 1968. Three distinct groups of Malacothrix were located within the approximate historic location of M. squalida, all within about 15 to $30 \mathrm{~m}$ (49 to $98 \mathrm{ft}$ ) of each other (fig. A-8). One of three patches of Malacothrix appeared to be M. squalida. Other patches appear to be $M$. indecora (18 plants) and hybrids of $M$. indecora and M. squalida (9 plants).

Table 19. Results of the surveys of Malacothrix squalida populations, the approximate area they occupy, and the total number in each population on Santa Cruz Island, California, 2006.

$\left[\mathrm{m}^{2}\right.$, square meter]

\begin{tabular}{ccccc}
\hline $\begin{array}{c}\text { Site } \\
\text { No. }\end{array}$ & Date & Site name & $\begin{array}{c}\text { Area } \\
\left(\mathbf{m}^{2}\right)\end{array}$ & $\begin{array}{c}\text { 2006 plant } \\
\text { counts }\end{array}$ \\
\hline 1 & not surveyed & Prisoners' Harbor & not surveyed & not surveyed \\
2 & $05-30-06$ & Potato Harbor & 6 & 23 \\
\hline
\end{tabular}

\section{Plant Voucher Specimens and Seed Collections}

Voucher specimens were collected at the Potato Harbor site from each of the three Malacothrix occurrences. The specimens have been sent to Malacothrix taxonomist W.S. Davis for identification and verification. They will be deposited at SBBG following verification. No seeds were collected.

\section{Thysanocarpus conchuliferus Greene (Santa Cruz Island lacepod)}

\section{Collection History}

Thysanocarpus conchuliferus is a small, annual herb in the Brassicaceae family, endemic to Santa Cruz Island only (Junak and others, 1995). The type specimen was collected on Santa Cruz Island in 1888 by T.S. Brandegee at an unspecified location. Specimens were collected from six sites between 1930 and 1934, and in 1941, R. Moran recorded a possible new occurrence in the "Pelican" area. At least 12 more sites were documented between 1967 and 1990. Table 20 lists $T$. conchuliferus populations in approximate order of discovery; the list is based on voucher specimens housed in California herbaria and reported by the Consortium for California Herbaria (University of California, 2007). T. conchuliferus currently occupies north-facing rock outcrops and buttes, from canyon bottoms to ridge tops, but Hochberg and others (1980) report that this species was more common in locations scattered across the island early in the 1900s.

\section{Field Surveys}

Surveys of $T$. conchuliferus historical sites and potential habitat spanned the growing seasons of 2003-2006. Most early collections have vague location information, making positive relocation of many historic occurrences difficult, if not impossible. We used our knowledge of $T$. conchuliferus habitat requirements along with whatever location information was available with each herbarium specimen (for example, "lower Lady's canyon, north-facing slope") to search areas where we had a reasonable chance to find the collection site. We believe that we relocated the original population when our observations generally matched the information on the herbarium label. Table 20 summarizes results of our visits to these historical sites in the categories of historical locations that we were certain we relocated, possible re-locations of historical sites, and new discoveries (that is, no indication from any source that a population was known from the area in the past). Table 20 shows the number of plants seen during our surveys and the approximate area of the populations; figure A-9 shows their locations.

In March 2003, we used a helicopter and a team of six botanists to search for seven historic sites known to Steve Junak (S. Junak, Santa Barbara Botanic Garden, oral commun., 2003). Plants were found at two of these sites, up the canyon from Lady's Harbor beach (Lower Lady's, Site 1 , figs. 1, A-9) and in the upper west fork of Orizaba Canyon (Site 15, figs. 1, A-9). During this trip we surveyed the Picacho Diablo region where a large population had been seen by Junak in the 1980s (Sites 9 and 10, fig. A-9); six botanists thoroughly searched this area for several hours and found no plants. The best known historical site (Site 17, fig, A-9), located in the Central Valley west of the Portezuela Ranch ruins, was visited annually in March of 2003 through 2006. This site was visited nearly annually by SBBG and TNC botanists in the 1980s and early 1990s, and plants have been consistently present, although few and declining in number (S. Junak, Santa Barbara Botanic Garden, oral commun., 2003). In 2006 and 2007, no plants were at this site.

During March and April 2004, surveys for T. conchuliferus focused on the region north, northwest and west of Picacho Diablo and east of Lagunitas Secas, where several T. conchuliferus collections were made from 1969 to 1980. Numerous rock buttes and rock outcrops are in this general area, both in canyon bottoms and on slopes and ridges. Several dozen buttes and outcrops were searched in areas with good potential habitat during the flowering and fruiting season. Three populations were located in the upper reaches of the east fork of the canyon leading down from the Pichaco Diablo area to Trident and Lady's Harbors (Trident Canyon, Sites 18, 19, and 20). These are listed as possible historical sites in table 20 and shown on figure A-9. 
Table 20. Results of the surveys of Thysanocarpus conchuliferus populations, the approximate area they occupy, and the total number in each population on Santa Cruz Island, California, 2003-2006.

[ , about; nc, no counts made because not surveyed]

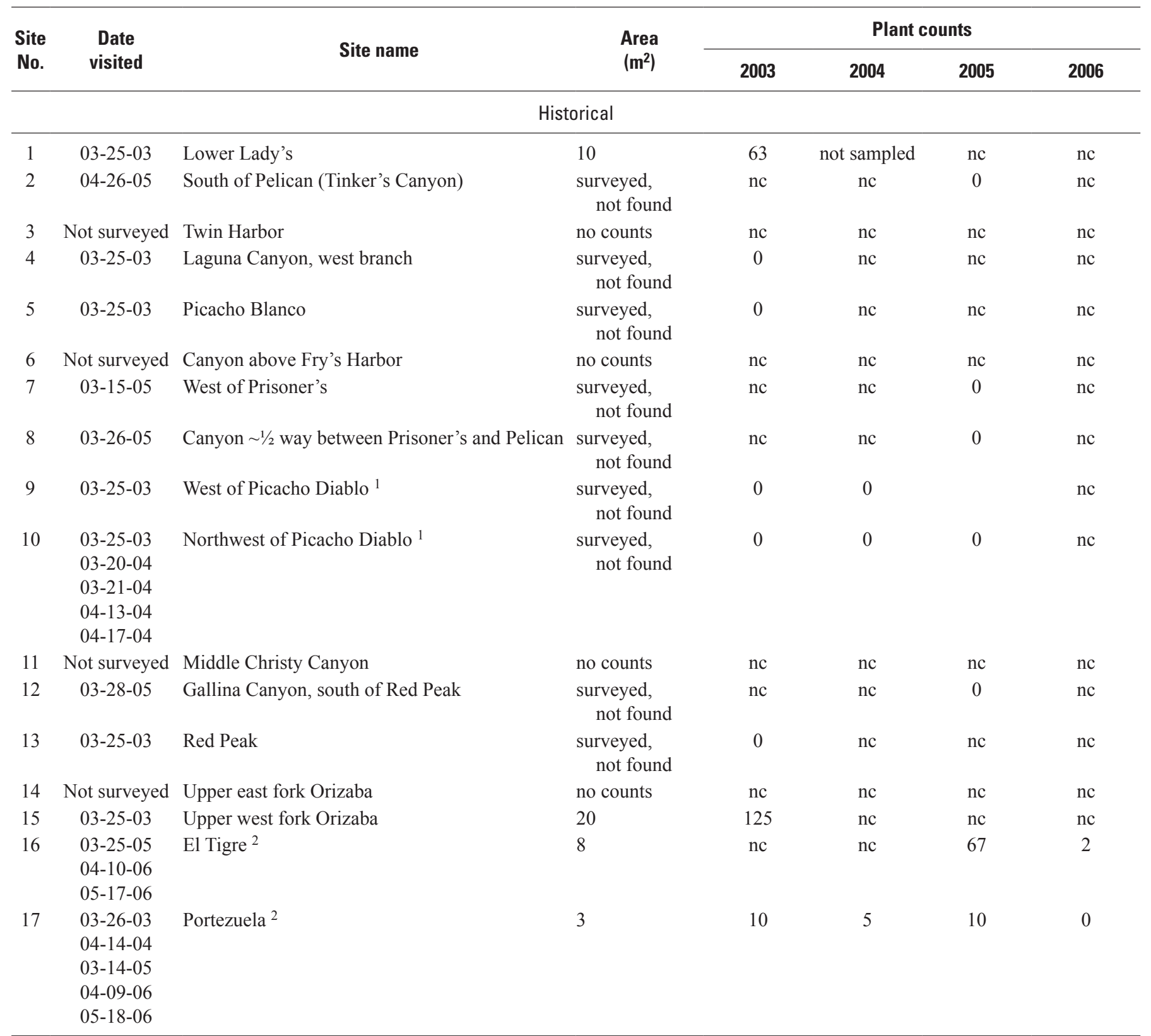

\begin{tabular}{|c|c|c|c|c|c|c|c|}
\hline \multicolumn{8}{|c|}{ Possible historical sites } \\
\hline 18 & $\begin{array}{l}04-13-04 \\
03-12-05 \\
04-29-06\end{array}$ & Trident Ridge $^{2}$ & 100 & $\mathrm{nc}$ & 219 & 755 & 3 \\
\hline 19 & $\begin{array}{l}04-17-04 \\
03-13-05 \\
05-16-06\end{array}$ & Trident-Lady's Ridge west ${ }^{2}$ & 90 & $\mathrm{nc}$ & 203 & 359 & 24 \\
\hline
\end{tabular}


Table 20. Results of the surveys of Thysanocarpus conchuliferus populations, the approximate area they occupy, and the total number in each population on Santa Cruz Island, California, 2003-2006. - Continued

[ , about; nc, no counts made because not surveyed]

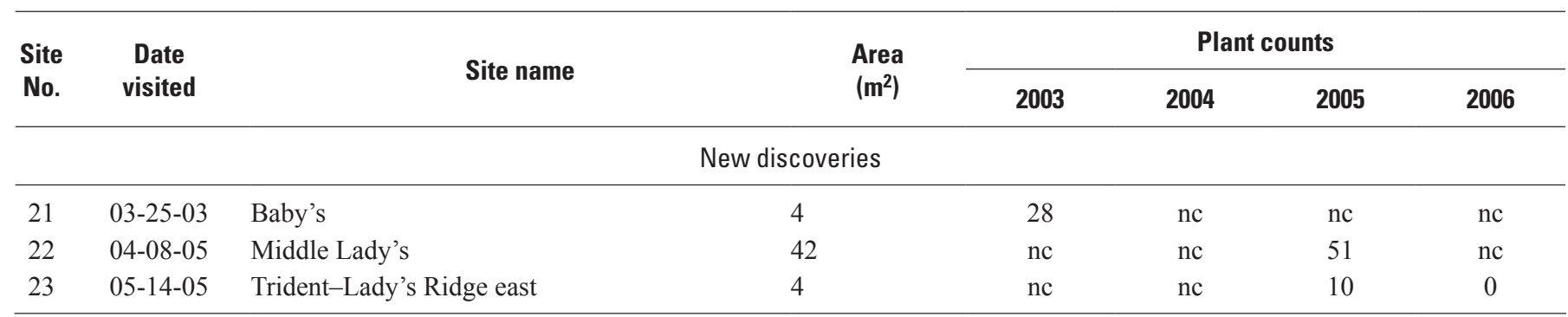

Surveys for 2005 began in March and were extended into May because of the unusually high late-spring rainfall. We searched potential habitats along the Pelican Trail from Prisoners Harbor to Pelican Bay, and up Tinkers Canyon above Tinker's Cove, in Gallina Canyon north of the Main Ranch, Lady's Canyon, and El Tigre ridge. We found $T$. conchuliferus plants in Lady's Canyon at an apparently new site, and along the El Tigre Ridge, a historical location. In addition, a small group of ten plants (Site 23) was just above the new Arabis hoffmannii site called Trident-Lady's Ridge

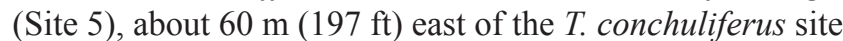
mapped in 2004, also called Trident-Lady's Ridge (Site 19).

There were no additional surveys for T. conchuliferus in 2006, because numbers of plants at demography sites were low, indicating that $T$. conchuliferus was having a poor year, and obscure populations would be probably be difficult to see.

\section{Plant Voucher Specimens and Seed Collections Details}

Voucher specimens were collected from five $T$. conchuliferus populations in 2005. Seeds were collected in 2005 from the three Trident Canyon sites (Sites 18, 19, and $20)$ as well as the El Tigre site, the only site relocated on the south side of the island.

Since flowering was poor in 2006, T. conchuliferus seeds were collected only from two large plants at the TridentLady's Ridge (Site 19). Table 21 summarizes seed and voucher specimen collections. Approximately two-thirds of the seeds were put into the seed bank at the Santa Barbara Botanic Garden. The remainder were used in seed viability tests, and the resulting plants were grown to produce more seeds for seed banking and outplanting experiments.
Table 21. Thysanocarpus conchuliferus seeds and voucher specimens collected 2004-2006, Santa Cruz Island, California.

\begin{tabular}{|c|c|c|c|}
\hline \multirow{2}{*}{$\begin{array}{c}\text { Site } \\
\text { name }\end{array}$} & \multicolumn{2}{|c|}{ Total seeds } & \multirow{2}{*}{$\begin{array}{c}\begin{array}{c}\text { Voucher } \\
\text { specimens }\end{array} \\
2005\end{array}$} \\
\hline & 2005 & 2006 & \\
\hline Trident Ridge & 157 & 0 & 1 \\
\hline Trident-Lady's Ridge west & 50 & 63 & 1 \\
\hline Upper east fork Trident & 36 & 0 & 1 \\
\hline El Tigre & 29 & 0 & 1 \\
\hline Middle Lady's & 0 & 0 & 1 \\
\hline
\end{tabular}

\section{Discussion}

The federally listed plants of Santa Cruz Island span a range of life histories; these plants include three annual herbs and one perennial herb, a diminutive succulent, two sub-shrubs and two full shrubs. All have a high degree of habitat specificity and have always been patchy and rare in their distribution on the island. They are listed as threatened or endangered now because their distribution became even more restricted as ranching damaged plants and habitats, constraining opportunities for population growth and connectivity over the past century. Many of the factors affecting the recovery potential of these listed taxa are related to the ecological conditions of the habitats or the island environment, such as annual grass invasionncthey are extrinsic to the taxa and affect several taxa similarly across the entire island. Other factors, such as seed viability rates, are related more to the particular ecology and life-history of each taxon - these are intrinsic to each taxon and become apparent at the population level. Our survey results provide a way of categorizing these factors, first by looking broadly at patterns emerging across the surveyed taxa, and then more closely within taxa at the populations that we found and censused. 


\section{Collections Information and Search Strategy}

We found collections information from as long ago as the late 1800 s, although most of the oldest records available to us dated from the late 1920s through the 1930s. Collections were made sporadically throughout the 1900 s, and many of the rare plant populations had not been visited since the 1980s or earlier. Sheep were removed by 1980 on the western 90 percent of the island and by 1999 on the eastern 10 percent. We placed high priority on getting to sites not visited since sheep removal and on surveying the rarest plants, such as M. fasciculatus var. nesioticus and B. pinnata ssp. insularis, taxa with only 4 and 5 known individuals each. In certain other cases, a population had been recorded, but no voucher or photograph had been collected, so we placed high priority on finding and verifying these sites as well. Finally, the locality information in the historic record ranged from vague and very general site descriptions recorded with the earlier collections to descriptions recorded using coordinates drawn from topographic maps in the field or recorded with recent global positioning systems technology. About one-third of the records were so vaguely worded that we could not locate the sites on a map with any certainty. Where at all possible, we put high priority on finding some of those more vaguely described sites so that we could record better locality information. Otherwise, our search strategy was to re-locate as many rare plant populations as possible, but to stratify the search over the range of environments in which the taxon had been recorded to get the most complete picture of its ecological tolerances. For example, we searched the south ridge near el Tigre extensively to find a $T$. conchuliferus site, because this is a habitat potentially unlike others described for the species where plants might fare differently from other sites. Our search time was greatly extended for those uncertain localities in comparison to sites that were more clearly documented with spatial coordinates recorded in the field and a brief description of the local habitat. Thus, we kept careful metadata on locations so that our information will be useful for future surveys and spatial habitat analyses.

$H$. greenei was the sole exception to this search strategy. It is a short-lived, small and delicate sub-shrub that germinates after fires (S. Junak, Santa Barbara Botanic Garden, oral commun., 2002), and in barren, open sites. We observed many small populations in scattered open habitats across the entire island during other field studies 2001-2003. Therefore, we simply mapped this species as it was encountered, rather than searching out specific sites with often uncertain locality information from the past. We found 22 small populations of H. greenei in our studies 2001-2006, and estimate that there may have been as many as 40 more populations seen but not clearly documented by others since sheep removal.

\section{General Patterns}

The majority of populations that we could map from the historic record still existed: we searched for 49 sites and found that 39 of them, or 80 percent, were still extant. The locality information for nine other populations was clear enough to expect that we were at the historic collection site, but we found no plants despite searching for most of them several times during the study period. Although these may be locally extirpated populations, it is also possible that we visited while plants were dormant and missed the plants for our search year. These sites are given in the tables and figures presented for each taxon, so that they can be resurveyed in the future.

The populations we found were small and isolated, often separated by many kilometers from the next nearest known occurrence of the same taxon. This distribution reflects the habitat specialization of many of these taxa, but the isolation is exacerbated by extirpation from formerly occupied and potential habitats, many of which we surveyed and found empty. Population sizes ranged from single individuals for the clonal shrubs up to as many as several hundred plants for some annuals, the perennial Arabis hoffmannii, and the two sub-shrubs. By far the largest was the D. nesiotica population at Fraser Point, with several thousand individuals. We expect large inter-annual variability in annual plant population size, so these one-time surveys should be taken as an indicator of population status that is better understood in annual plants with repeated censuses over a range of years. Finding known and mapped sites of T. conchuliferus was particularly difficult, perhaps because of dormancy at the time of our surveys even though we searched during the same time that other populations were flowering

The habitats occupied by the suite of listed taxa are generally distinct, native-dominated habitat patches in a matrix of nonnative herbaceous vegetation, barrens, highly fragmented chaparral, coastal scrub, or woodland. In almost all cases, the occupied habitat patch had an abrupt edge and the listed taxon, along with its native community associates, had not established individuals beyond the border. These occupied habitats stand out as small refugia where natives still persist. Whether the rare plants can expand at the borders of these sites or disperse from them to other locations will depend on intrinsic factors, like their fecundity, vigor, competitive abilities, and capacities for long-distance dispersal, and the amelioration of environmental factors that now constrain their expansion. While the surveys did not provide detailed data on demographic characteristics, we did note whether fruits and seeds were being produced, recorded whether a range of size or stage classes were present in the populations of nonannuals, and looked for evidence of colonization at the verges of the habitat patches. 
Since the pigs have been removed, population growth by expansion at the habitat edge may be possible for several listed taxa, such as A. hoffmannii, D. nesiotica, G. buxifolium, H. greenei., and M. fasciculatus var. nesioticus. All these taxa had vigorous individuals with good seed production and a range of size classes within populations that indicates recent recruitment. Recovery of native community composition and cover may be the key to population increase by expansion for these taxa. However, several taxa, including A. hoffmannii and T. conchuliferus, have such isolated populations that despite good seed production, they may not be able to colonize other sites. Outplanting to increase population numbers may be a good recovery strategy for these taxa. In addition, two taxa are represented by so few populations and so few individuals that they need active intervention to increase their numbers. These include the annuals $M$. indecora and M. squalida; only two to three known populations with several dozen to about 100 plants each exist, occupying eroding and highly invaded coastal bluff terraces. We documented 21 occurrences of G. buxifolium, all growing on vertical, north-facing cliffs overhanging the ocean. While this is a relatively large number of occurrences compared with those of other taxa, these populations may be more at risk than others from slumping of the bluff face and habitat loss. We observed bluff slumping during the winter of 2004-2005 in the Prisoners' Harbor and China Harbor areas, and part of one of the Cañada del Agua G. buxifolium populations was lost. Therefore, maintenance of many occurrences would be best to buffer this species from coastal bluff erosion. Neither of the full shrubs $M$. fasciculatus var. nesioticus nor B. pinnata ssp. insularis produced mature fruits in the field during our survey period, although they can be induced to do so at the SBBG by hand-pollination (Wilken 1996). We know of only 4 or 5 wild individuals of these taxa, and both are thought to be extirpated from other Channel Islands; clearly they are still at risk. It is unclear from our work why these plants do not produce fruits in the wild, but observations point to lack of pollinators for $M$. fasciculatus var. nesioticus and insect flower and fruit predation, and perhaps other factors for B. pinnata ssp. insularis. Both plants are strongly clonal in the field, but only $M$. fasciculatus var. nesioticus has responded well to propagation by live cuttings. Given that we cannot get good material for propagation from wild B. pinnata ssp. insularis, hand pollination and flower and fruit protection coupled with tissue culture appear to be the best techniques to aid its recovery.

\section{Conclusions}

Our objective for this study was to provide information and materials useful for planning and managing recovery of the nine listed plant taxa of Santa Cruz Island. Our goals were to evaluate the current status of known, historical populations of the listed plant taxa and their habitats and to provide voucher specimens, seed for banking, and cuttings for off-site conservation to fill gaps in the collections materials. We developed a database of historical records from local and regional herbaria, field notes, and published and unpublished reports and used it to guide rare plant field searches in the growing seasons of 2003 through 2006. We found that a majority of the known historical populations still exist, indicating a resilience to the changes of the past. The populations are generally small and isolated, occupying native-dominated habitat patches in a highly invaded and fragmented landscape. Most of the taxa appear to have the intrinsic capacity to increase, as evidenced by good seed production and a diversity of size classes of individuals in populations. The challenges for recovery of these taxa will be environmental: they will need to expand beyond the boundaries and disperse to other sites for recovery to occur. Some taxa may need intervention to achieve larger and more numerous populations, but there do not appear to be innate problems with propagule production. A few taxa have so few individuals left in the wild that they need special attention soon, including collecting seeds for greater seed production in the greenhouse, establishing new populations, experimenting with pollination to achieve fruit set, and pursuing tissue culture to conserve island genomes.

Santa Cruz Island ecosystems have a real chance for recovery for the first time in more than a century, now that all of the feral livestock are gone. Recovery may take various pathways across the different environments of the island, and some sites may change faster than others. Natural vegetation recovery should include returning dominance of native plants, developing more nearly continuous shrub and tree canopies as stands grow and recruit new individuals, recovering more mesic understory conditions in woody stands, increasing plant vigor as soils regain their tilth, and accumulating seeds and underground roots and stems in a soil and litter-duff layer. All of these factors should benefit the rare and listed plants, but how they will respond depends to a large extent on their genetic and demographic structure at the population level. However, the same conditions that originally supported the listed taxa may not be re-established: non-native plants are prominent members of the plant communities across much of the island now, and the flora, hydrologic regimes, and soil systems have changed as well. Therefore, recovery will depend as much on the community and habitat context as on population function in the rare plant taxa. This study gives us information on the resilience of the listed plant populations over the past century, identifies the raw materials for recovery currently assembled in the field populations, identifies several cases where recovery actions are needed, and provides some materials for managed intervention. This survey contains important baseline information on the distribution and abundance of listed plant populations. It shows the range of environmental conditions they now tolerate and can aid conservation planning for the future. 


\section{Acknowledgments}

Several individuals shared their knowledge and provided field time and logistical support for this project, particularly Matthew Barmann, Steve Junak, Dieter Wilken, Steve McCabe, Clark Cowan, Lyndal Laughrin, Karen Flagg, Sarah Chaney, Dirk Rodriguez, the Channel Islands National Park Transportation Division, and Channel Islands National Marine Sanctuary. Coleen Cory and Dieter Wilken provided valuable comments on the report. This study was funded in part by grants from the National Park Service Biological Inventory and Monitoring Program, the National Park Service National Resource Protection Program, Channel Islands National Park, the Nature Conservancy, the Santa Barbara Botanic Garden and the University of California Santa Cruz Island Reserve. Work was conducted under U.S. Fish and Wildlife Recovery Research Permit \# TE-044846.

\section{References Cited}

Al-Shehbaz, M., Beilstein, A., and Kellogg, E.A., 2006, Systematics and phylogeny of the Brassicaceae (Cruciferae) - an overview: Plant Systematics and Evolution, v. 259, no. 2-4, p. 89-120.

Consortium of California Herbaria, 2007, Consortium Database, Regents of the University of California: Berkeley, California, University of California, accessed May, 2007, at http://ucjeps.berkeley.edu/consortium/.

Dempster, L.T., 1973, The polygamous species of the genus Galium (Rubiaceae) section Laphogalium of México and southwestern United States: University California Publications in Botany, v. 64, p. 1-36.

Dempster, L.T., 1993, Rubiaceae, in Hickman, J., ed., The Jepson Manual-Higher Plants of California: Berkeley, University of California Press, p. 976-986.

Guerrant, E.O., Jr., Havens, Kayri, and Maunder, M., eds., 2004, Ex situ plant conservation-Supporting species survival in the wild: Washington, D.C., Island Press, 536 p.

Hochberg, M., Junak, S., and Philbrick, R., 1980, Botanical study of Santa Cruz Island for the Nature Conservancy: Santa Barbara, California, Santa Barbara Botanic Garden.

Junak, S., Ayers, T., Scott, R., Wilken, D., and Young, D., 1995, A Flora of Santa Cruz Island: Santa Barbara, California, California Native Plant Society, 408 p.

Levine, J. M., McEachern, K., and Cowan, C. 2008. Effects of a fluctuating rainfall environment on rare island annual plants: Journal of Ecology 96:795--806.
McEachern, K., and Wilken, D., 2004, Implementing recovery actions for listed plants of Santa Cruz Island, Channel Islands National Park: NRPP Program Detailed Implementation Plan, USGS-BRD Channel Islands Field Station, Ventura, Calif., 12 p.

McEachern, K., Wilken, D., and Chess, K., 1997, Inventory and monitoring of California Islands candidate plant taxa: Sacramento, California, Western Ecological Research Center, U.S. Geological Survey Open-File Report 00-73. $46 \mathrm{p}$.

Munz, P., and Keck, D., 1959, A California flora: Berkeley, University of California Press, 1905 p.

Pavlik, B.M., 1994, Demographic monitoring and the recovery of endangered plants, in Bowles, M.C., and Whelan, C., eds., Recovery and restoration of endangered species: Cambridge, Massachusetts, Cambridge University Press, p. $322-350$.

Smith , J.P., Ken Berg, Loran May, 2001, Inventory of Rare and Endangered Vascular Plants of California: Sacramento, California, California Native Plant Society Press, 338 p.

U.S. Fish and Wildlife Service, 1997, Final rule for 13 plant taxa from the northern Channel Islands, California: Washington, D.C., U.S. Department of the Interior, Federal Register, v. 62, n. 147, p. 40954-40974.

U.S. Fish and Wildlife Service, 2000a, Recovery Research Permit for plants of the northern Channel Islands \#TE-044846: Ventura Field Office, Ventura, California, U.S. Department of the Interior.

U.S. Fish and Wildlife Service, 2000b, Thirteen plant taxa from the Northern Channel Islands Recovery Plan: Portland, Oregon, U.S. Department of the Interior, 94 p.

U.S. Fish and Wildlife Service, 2006, Recovery Research Permit for plants of the northern Channel Islands \#TE-044846 (renewal): Ventura Field Office, Ventura, California, U.S. Department of the Interior.

Wilken, Dieter, 1996, Reproductive strategies of four plants restricted to the northern California Channel Islands: Report to the U.S. Fish and Wildlife Service, Santa Barbara Botanic Garden, 42 p.

Williams, M., 1993, Berberidaceae, in Hickman, J., ed., The Jepson Manual-Higher plants of California: Berkeley, California, University of California Press, p. 362-364. 


\section{Appendix A. Historic and Current Occurrences of Federally Listed Plants on Santa Cruz Island, California}




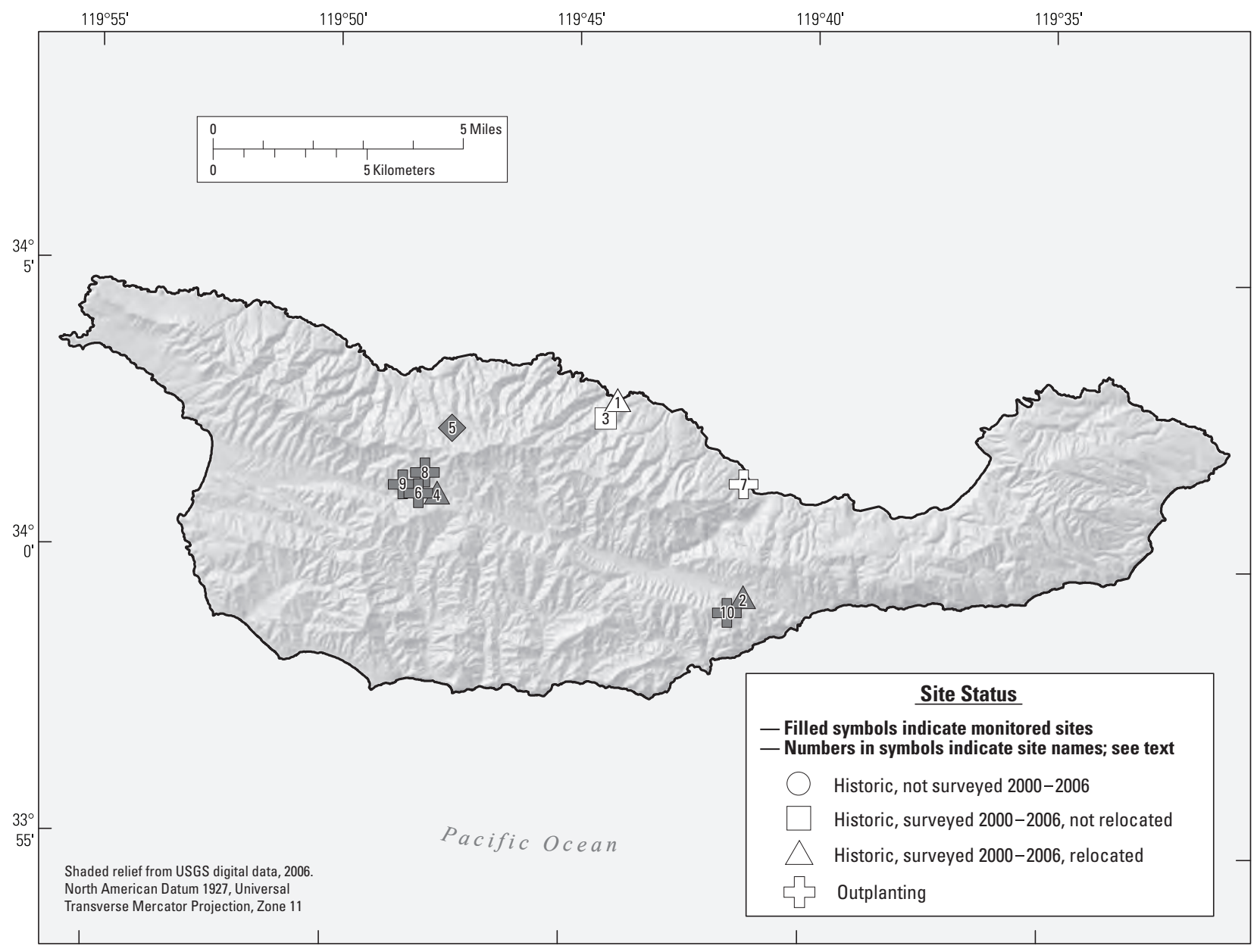

Figure A-1. Arabis hoffmannii (Hoffmann's rock-cress) USGS identified sites on Santa Cruz Island, California. 


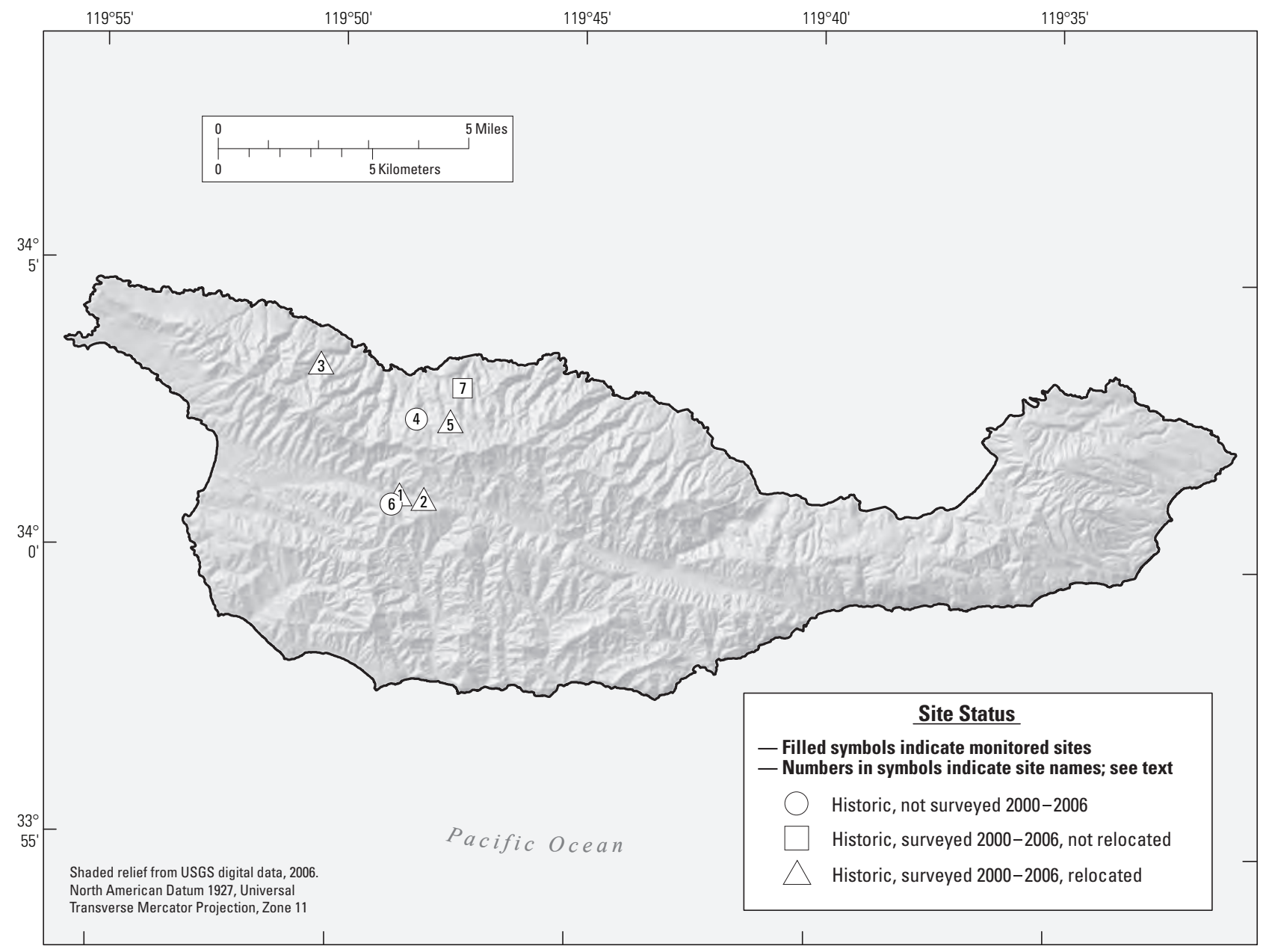

Figure A-2. Berberis pinnata ssp. insularis (island barberry) USGS identified sites on Santa Cruz Island, California. 


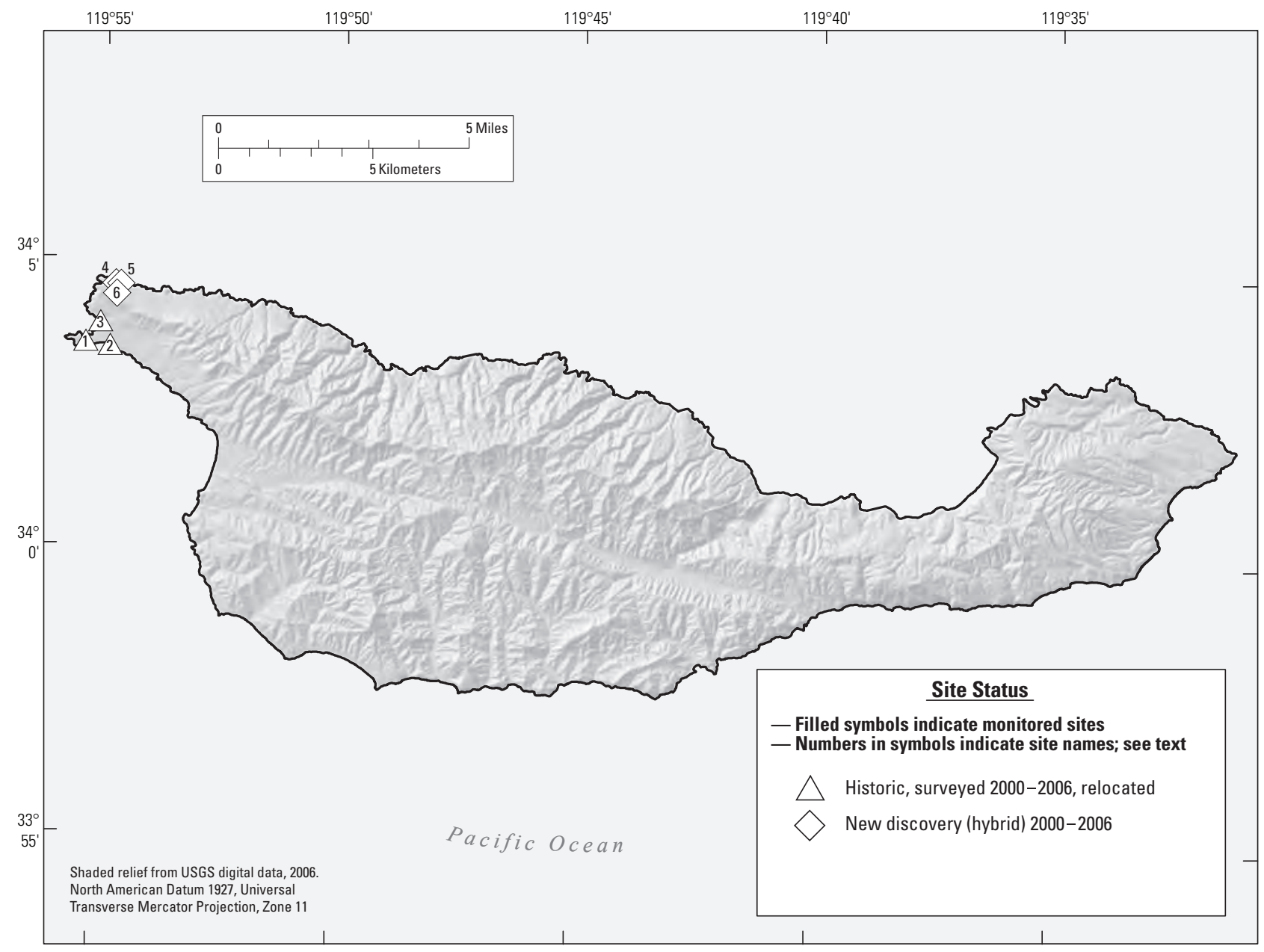

Figure A-3. Dudleya nesiotica (Santa Cruz Island live-forever) and hybrids USGS identified sites on Santa Cruz Island, California. 


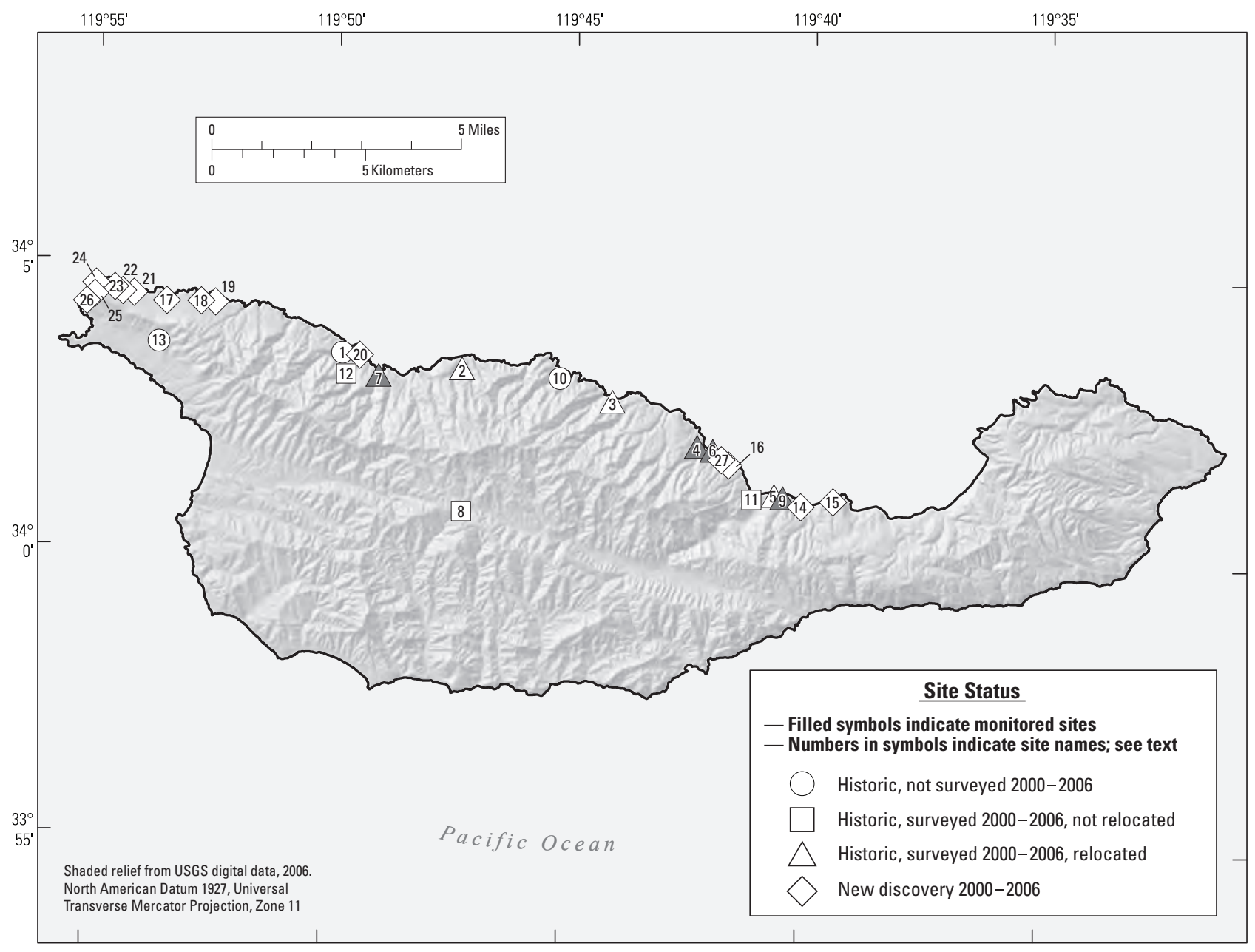

Figure A-4. Galium buxifolium (sea-cliff bedstraw) USGS identified sites on Santa Cruz Island, California. 


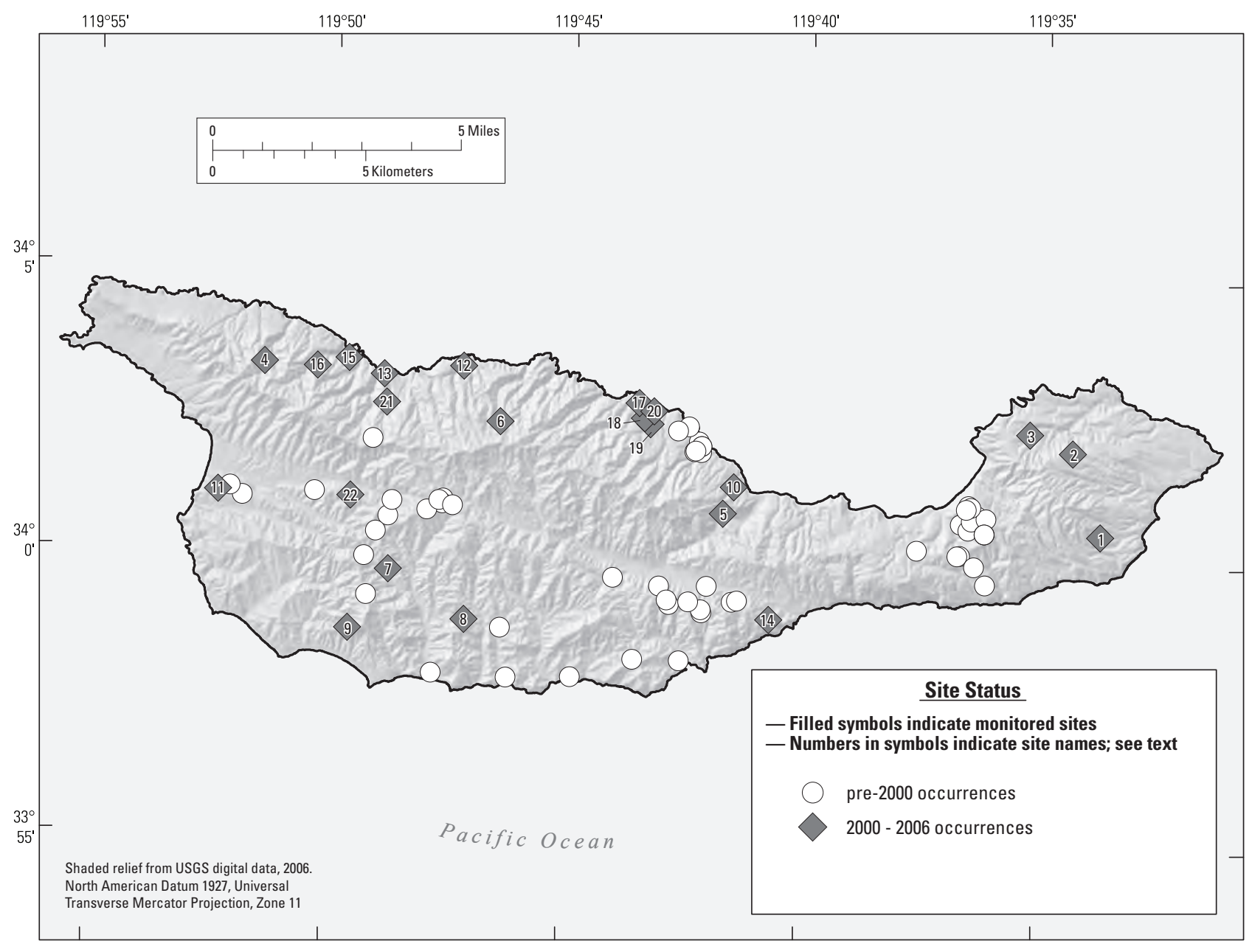

Figure A-5. Helianthemum greenei (island rush-rose) Santa Cruz Island, California. 


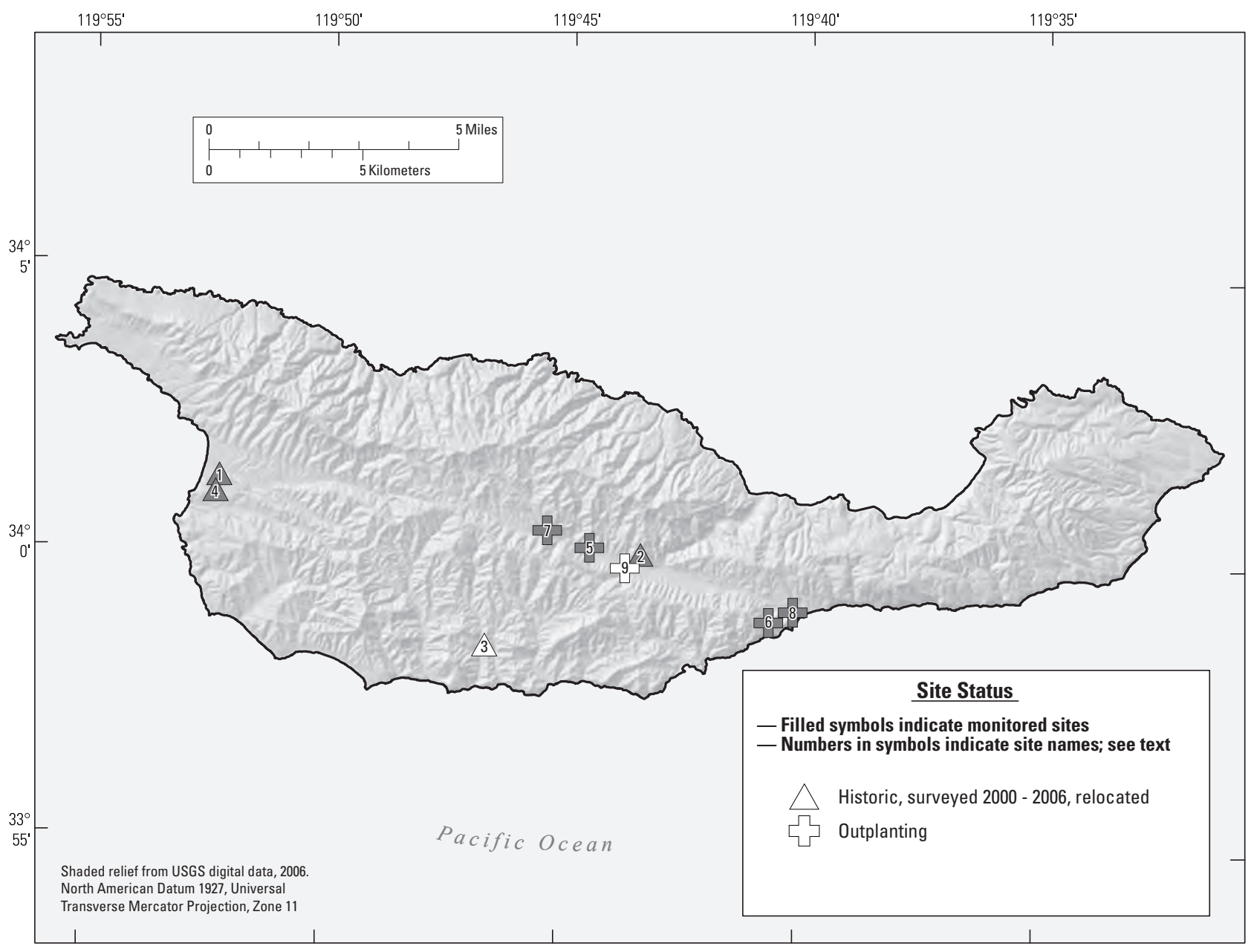

Figure A-6. Malacothamnus fasiculatus var. nesioticus (Santa Cruz Island bush malllow) USGS identified sites on Santa Cruz Island, California. 


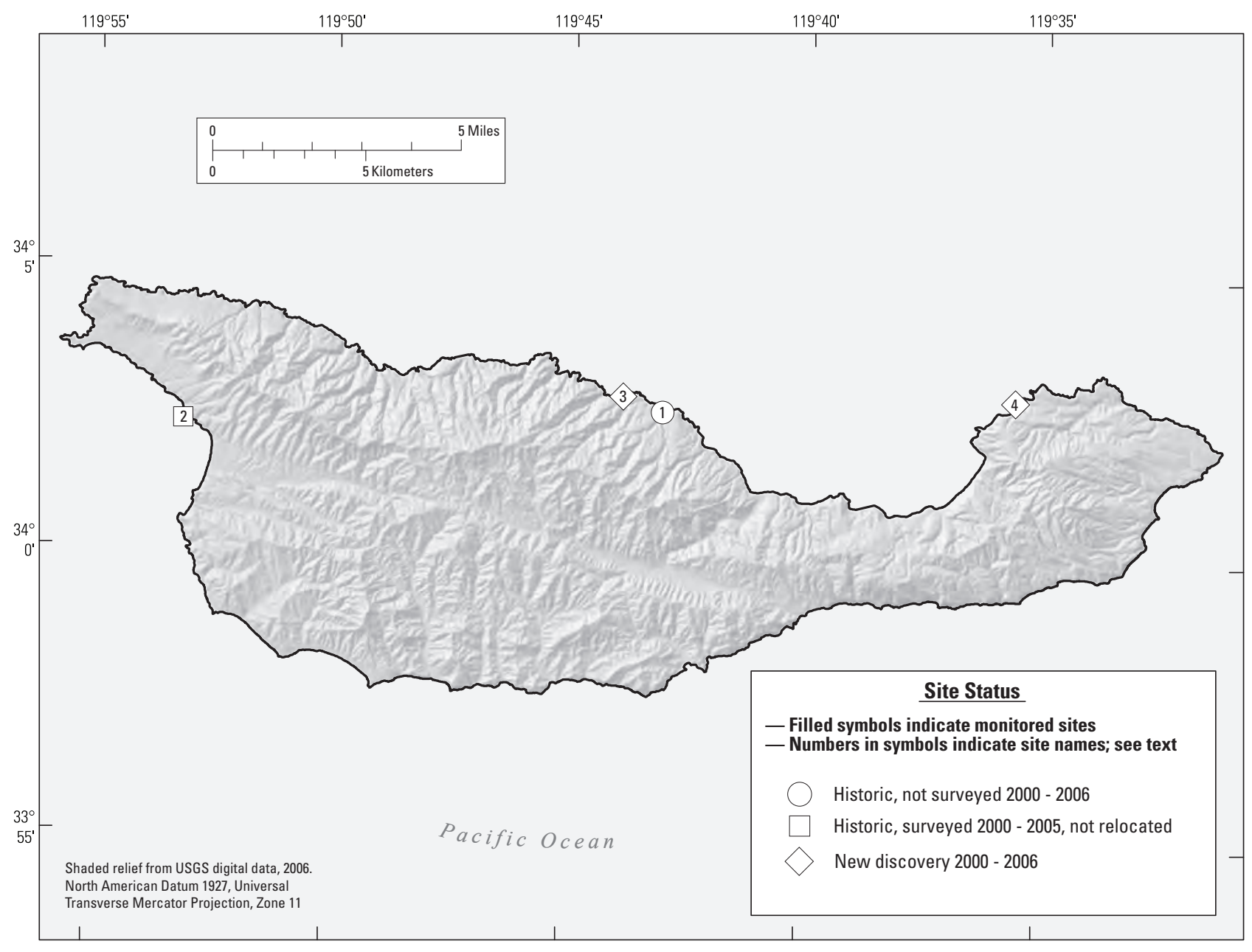

Figure A-7. Malacothrix indecora (Santa Cruz Island malacothrix) USGS identified sites on Santa Cruz Island, California. 


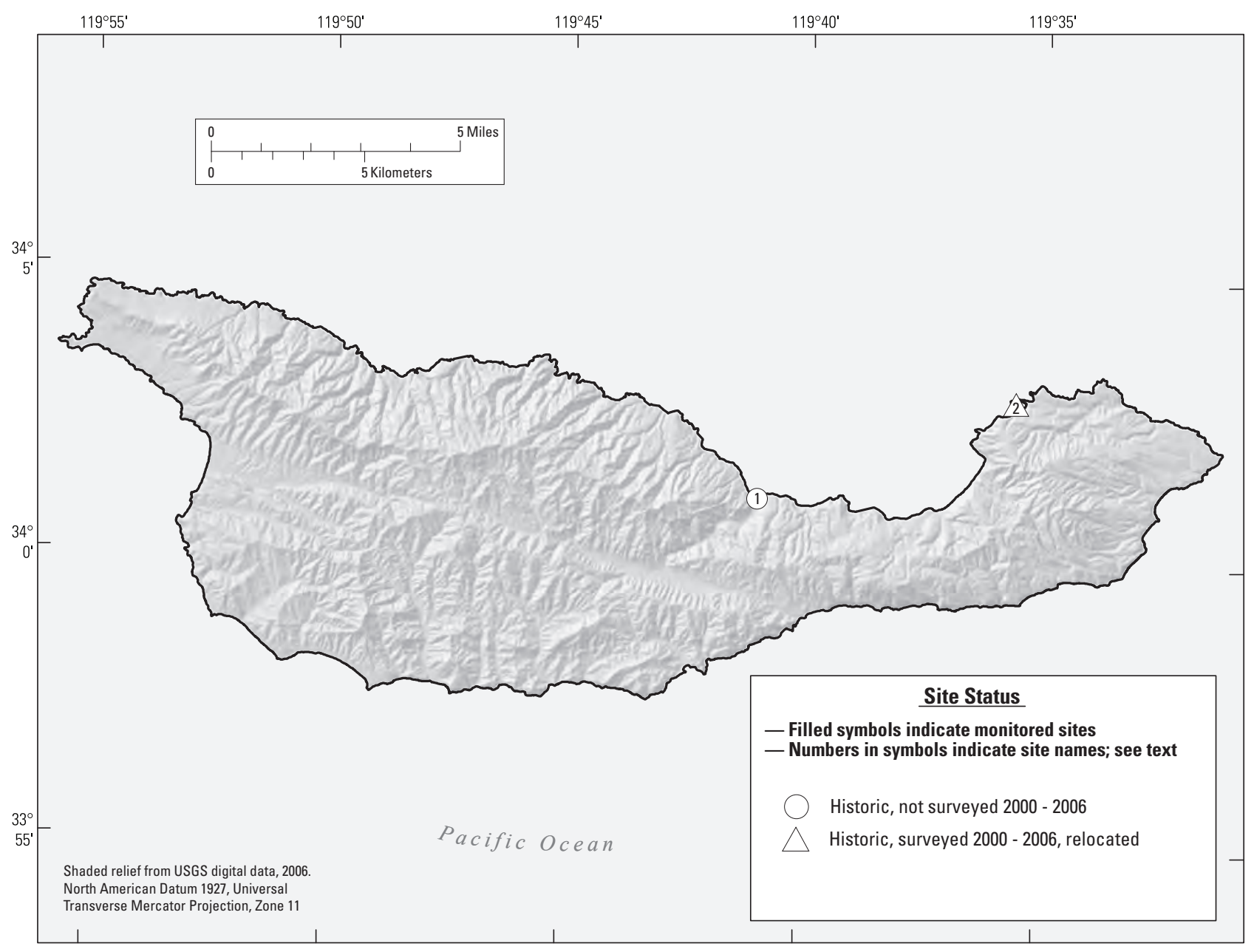

Figure A-8. Malacothrix squalida (island malacothrix) USGS identified sites on Santa Cruz Island, California. 


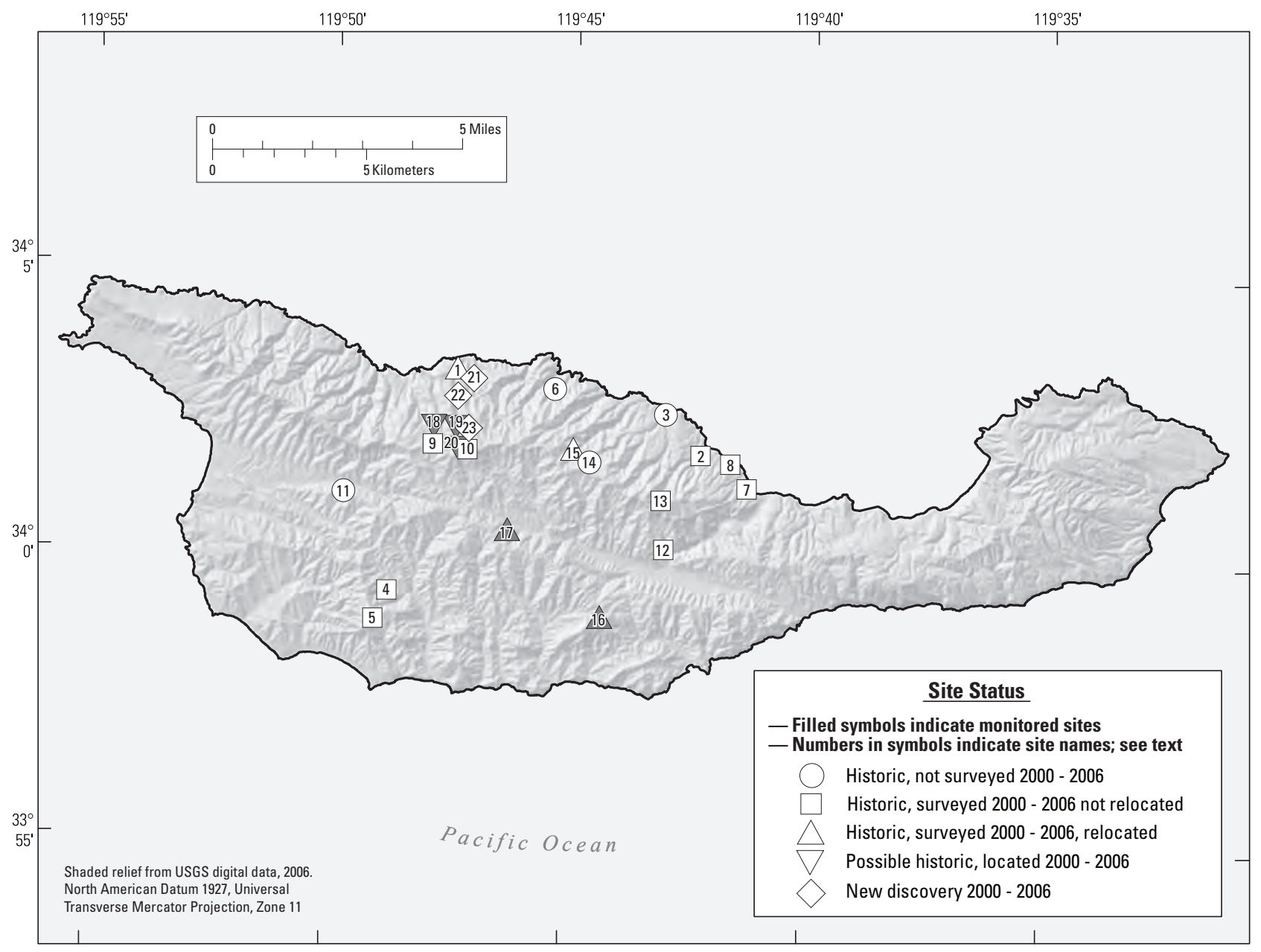

Figure A-9. Thysanocarpus conchuliferus (Santa Cruz Island lacepod) USGS identified sites on Santa Cruz Island, California. 


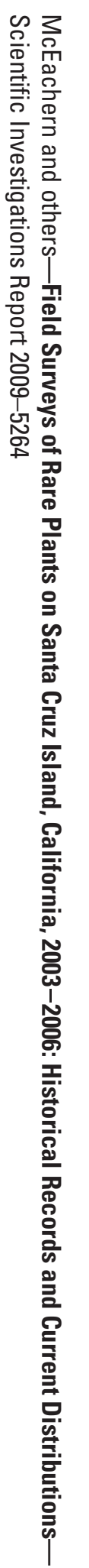

8 Printed on recycled paper 